\title{
THESIS
}

\section{ECONOMIC VIABILITY OF MULTIPLE ALGAL BIOREFINING PATHWAYS AND THE IMPACT OF PUBLIC POLICIES}

\author{
Submitted by \\ Jesse R. Cruce \\ Department of Mechanical Engineering
}

In partial fulfillment of the requirements

For the Degree of Master of Science

Colorado State University

Fort Collins, Colorado

Summer 2018

Master's Committee:

Advisor: Jason C. Quinn

Thomas Bradley

Jesse Burkhardt 
Copyright by Jesse R. Cruce 2018

All Rights Reserved 


\begin{abstract}
ECONOMIC VIABILITY OF MULTIPLE ALGAL BIOREFINING PATHWAYS AND THE IMPACT OF PUBLIC POLICIES
\end{abstract}

This study makes a holistic comparison between multiple algal biofuel pathways and examines the impact of co-products and methods assumptions on the economic viability of algal systems. Engineering process models for multiple production pathways were evaluated using techno-economic analysis (TEA). These pathways included baseline hydrothermal liquefaction (HTL), protein extraction with HTL, fractionation into high-value chemicals and fuels, and a small-scale first-of-a-kind plant coupled with a wastewater treatment facility. The impact on economic results from policy scenarios was then examined. The type of depreciation scheme was shown to be irrelevant for durations less than 9 years, while short-term subsidies were found to capture $50 \%$ of the subsidy value in 6 years, and $75 \%$ in 12 years. Carbon prices can decrease fuel costs as seen by the production facility through carbon capture credits. TEA tradeoff assessments determined that $\$ 7.3$ of capital costs are equivalent to $\$ 1 \mathrm{yr}^{-1} \mathrm{of}$ operational costs for baseline economic assumptions. Comparison of algal fuels to corn and cellulosic ethanol demonstrates the need for significant co-product credits to offset high algal capital costs. Higher value co-products were shown to be required for algal fuel economic viability. 


\section{ACKNOWLEDGEMENTS}

I would like to acknowledge Dr. Thomas Bradley and Dr. Jesse Burkhardt for their contributions as committee members for this work. Michael Somers and Evan Sproul are acknowledged for their research and non-research conversations and idea explorations, along with their editing assistance. Jennifer Markham is acknowledged for her wastewater modeling contributions. I thank Dr. Jason Quinn for his support and guidance of this work, and his never ceasing driving to look deeper and ask questions. And finally, I gratefully acknowledge my partner Anne Misak for her support, patience, understanding, sacrifice, and belief. 


\section{TABLE OF CONTENTS}

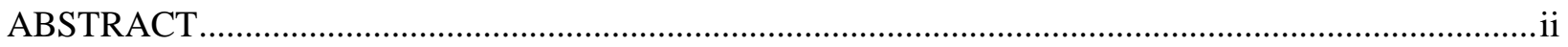

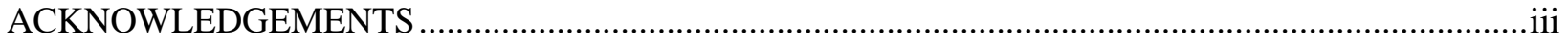

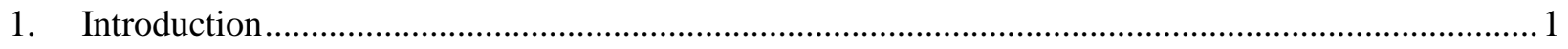

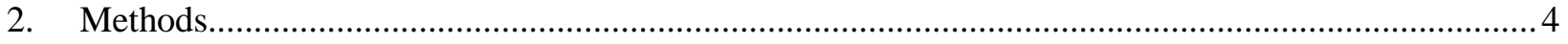

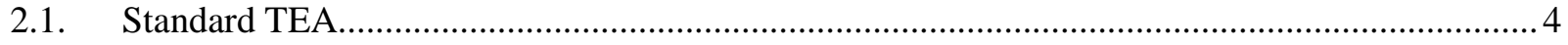

2.1.1. Engineering Process Model ...................................................................................... 4

2.1.2. Techno-Economic Analysis ….................................................................................

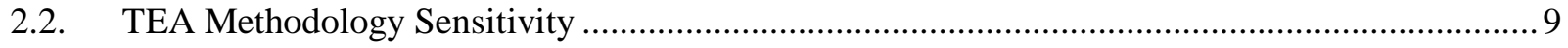

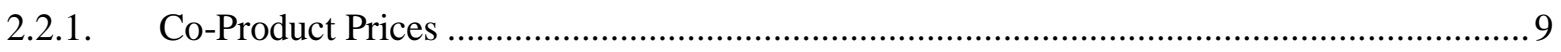

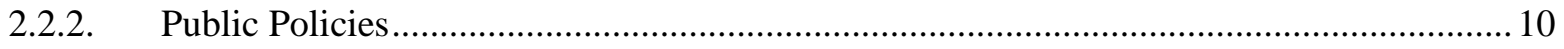

2.2.3. Carbon Price Policy ........................................................................................... 11

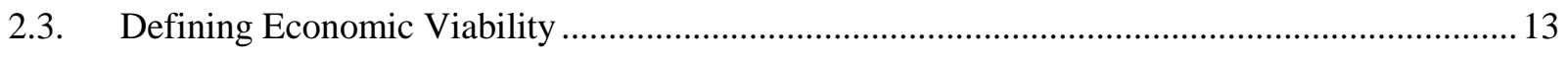

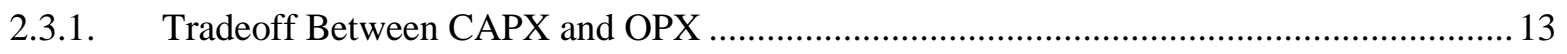

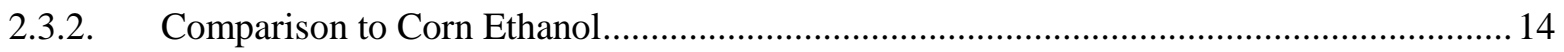

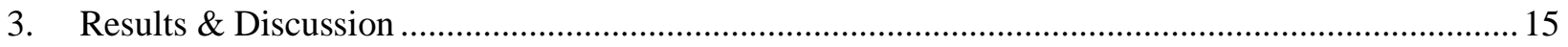

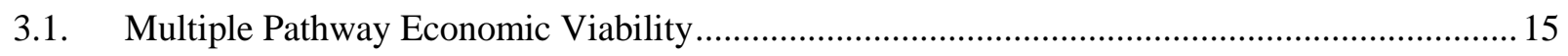

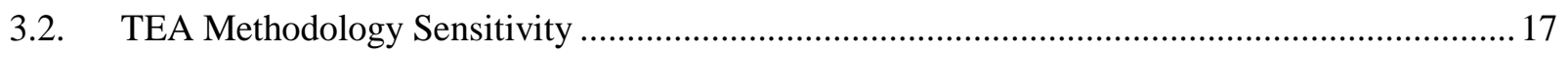

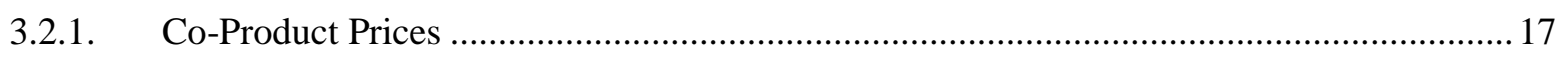

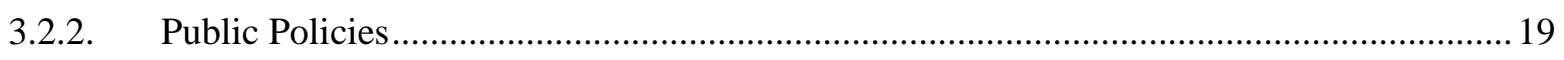

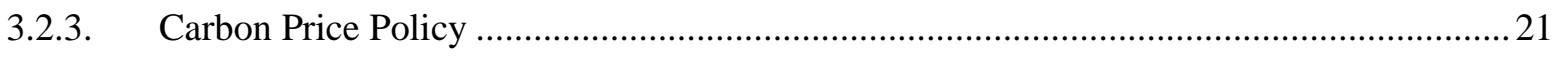

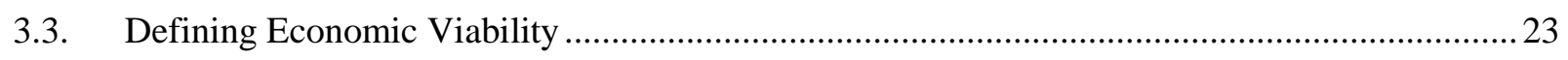

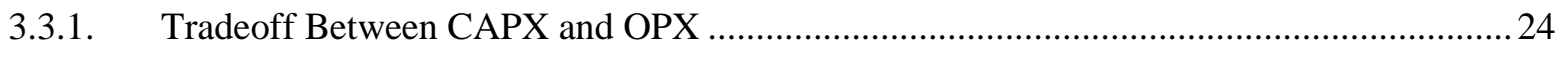

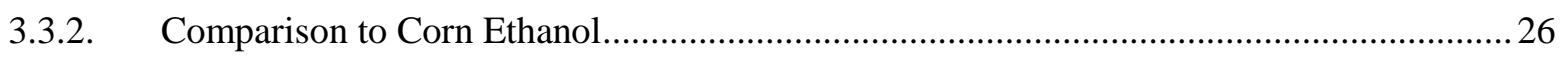

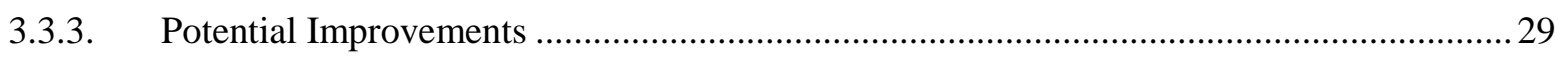

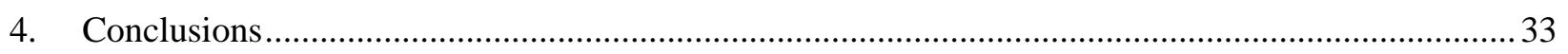

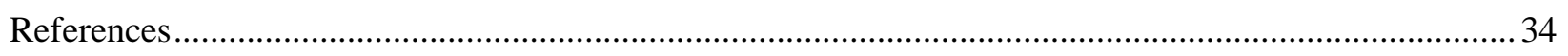

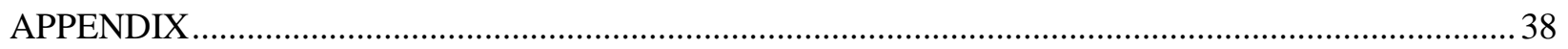




\section{Introduction}

Interest in biofuels as a potential replacement for fossil fuels dates back more than 50 years. Initially, geopolitical concerns about the continued reliability of petroleum imports spurred the research and development of domestic and renewable energy alternatives. Biofuels produced directly from food crops, namely ethanol from corn in the United States and from sugarcane in Brazil, were the first to see widespread commercial production (Solomon et al., 2007). However, more recent concerns about the sustainability of these first generation biofuels have increased interest in developing new biofuel pathways. Algae present one such alternative with several promising advantages over other feedstocks for biofuel production, including: high productivity; cultivation using saline, degraded, or wastewater sources on non-arable land; potential for genetic optimization; and the production of high value co-products (Carriquiry et al., 2011; Chew et al., 2017; Schenk et al., 2008; Williams et al., 2009). Despite these advantages, algal fuels have yet to become commercially viable, with estimated fuel costs still significantly higher than the $\$ 3$ per gallon of gasoline-equivalent (gge) target set by the Department of Energy (Schwab, 2016).

The sustainability of a biofuel production pathway is generally evaluated using techno-economic analysis (TEA) and/or life cycle assessment (LCA). Both require robust engineering process models detailing mass and energy flows through each production step, namely algal growth, harvest, and conversion or recovery of products. Previous research efforts have established both upstream (growth and harvest) and downstream (conversion) technologies for the primary production of fuel with potential for real world implementation. The predominate upstream systems are based on cultivation in open raceway ponds (ORPs) followed by multi-stage dewatering (Davis et al., 2016). A variety of downstream processing technologies are being explored, including lipid extraction and upgrading (Davis et al., 2011; Gnansounou and Kenthorai Raman, 2016; Mu et al., 2017; Quinn et al., 2014; Richardson et al., 2012); hydrothermal liquefaction (HTL) for conversion of algal biomass into biocrude (Barlow et al., 2016; Beal et al., 2015; Jones et al., 2014; Li et al., 2017; Selvaratnam et al., 2015; Summers et al., 2015), and 
fractionation processes that convert the biomass into separate carbohydrate-, lipid-, and sometimes protein-derived fuels and products (Davis et al., 2014; DeRose et al., 2018). However, despite process improvements and optimistic performance scenarios, these fuel-only pathways still typically fail to reach cost parity with fossil fuels, in part because the high cost of biomass production limits the benefits available through advances in downstream processes. Increased productivity is often cited as a major opportunity for cost decreases; however, Davis et al. (2016) notes limited benefits beyond $35 \mathrm{~g} \mathrm{~m}^{-2} \mathrm{day}^{-1}$, with the resultant biomass costs still too high. This challenge has increasingly spurred research efforts to explore high-value co-products to offset fuel costs. The co-production of electricity or high-protein feed alongside fuels has seen the most attention (Batan et al., 2016; Beal et al., 2016, 2015; Davis et al., 2011; Kern et al., 2017; Richardson et al., 2012; Vanthoor-Koopmans et al., 2013; Walsh et al., 2016). Other studies have explored the production of higher value commodity chemicals such as succinic acid, or specialty compounds and pharmaceuticals (Chew et al., 2017; Gnansounou and Kenthorai Raman, 2016; Mata et al., 2010). While many of these studies include sustainability assessments, insufficient modeling work has been done to utilize co-product pathways to identify paths forward for algal fuels to achieve economic viability (i.e., $\$ 3 \mathrm{gge}^{-1}$ ).

The validity of sustainability assessment results is directly tied to the accuracy of the system models and assumptions (Quinn and Davis, 2015). For TEA, the $\mathrm{n}^{\text {th }}$ plant assumptions (Davis et al., 2016, 2014) have become a modeling standard. While this standardized TEA methodology is important for comparisons between alternative technologies and processes, it can be limited in its representation of realworld implementation. Some studies have improved on these methods by including price variability in their analyses (Batan et al., 2016; Kern et al., 2017). However, the results and single variable sensitivities generally presented by TEAs often do not fully illuminate paths forward for algal fuels to become competitive with petroleum and first-generation biofuels. Emerging higher value co-product pathways offer potential, but the production of a significant portion of process revenue through non-fuel products can lead to results significantly impacted by co-product price assumptions. Alternatively, the impact of public policies benefiting algal fuels in ways similar to previous support for corn and cellulosic ethanol 
has seen some consideration (Amanor-Boadu et al., 2014; Hise et al., 2016). However, neither AmanorBoadu et al. (2014) nor Hise et al. (2016) gives a full accounting of the specific impacts of each policy option, instead presenting them as parts of scenarios. Similarly, carbon pricing policies have seen little integration into algal biofuel analyses; the closest is Amanor-Boadu et al. (2014), which includes a tax on fossil fuels that funds a subsidy program for algae, but does not discuss the impact on the overall biofuel costs. Altogether, these various questions have been insufficiently explored for algal biofuel systems and represent key areas for a better understanding of what it takes for algae systems to achieve real-world implementation.

This study makes a holistic and expanded examination of the impact from co-products and methodology assumptions on the economics and sustainability of algal biofuel systems, with a goal of informing the requirements for these systems to become cost competitive with petroleum and firstgeneration biofuels. Engineering process models were developed for representative biofuel and coproduct pathways, which utilize a common upstream of ORP growth and three-stage dewatering followed by conversion of a baseline HTL, bulk protein extraction integrated with HTL, fractionation, and a smallscale first-of-a-kind plant with HTL. The developed models were foundational to assess the sustainability of these pathways using TEA and LCA. The impact on these baseline results from methodological assumptions and real-world scenarios was examined, including that from co-product prices, public policies used to support corn and cellulosic ethanol starting in the 1970s applied to algae, and carbon pricing schemes based on the social costs of carbon. The results from these studies were leveraged to make observations about the requirements for algal biofuels to become commercially viable. The tradeoffs between upfront capital and recurring operating costs were examined and used to compare algal systems to corn and cellulosic ethanol. 


\section{Methods}

This study provides a holistic treatment of algal biofuel pathways combined with high-value co-

products. System modeling and standard TEA methods are presented. These models and results were then used to examine the impact of assumptions and methodology, with a focus on real-world scenarios.

\subsection{Standard TEA}

Engineering process models with detailed mass and energy balances were developed for multiple algal biofuel pathways. These engineering process models were constructed modularly to support the evaluation of different pathways and were foundational for establishing baseline TEA results.

\subsubsection{Engineering Process Model}

Sub-process models were developed and validated through literature for demonstrative biofuel and co-product pathways utilizing a common framework of assumptions. Four scenarios were developed based on an open raceway pond (ORP) growth architecture and three-stage dewatering followed by: (1) a baseline case of direct HTL of algal biomass; (2) bulk protein extraction followed by HTL of the remaining biomass; (3) a fractionation process converting carbohydrates to a representative high-value chemical and proteins to fusel alcohols, with HTL of the remaining biomass; and (4) a small scale, firstof-a-kind (FOAK) plant coupled to a wastewater treatment facility, utilizing direct HTL of the biomass combined with sludge from the treatment facility (Figure 1). All fuel production results were updated to a gallon-of-gasoline-equivalent (gge) basis using low-heating values listed in GREET (Argonne National Laboratory, 2017).

Growth: All four scenarios utilize an ORP for algal cultivation followed by three-stage dewatering, based on the work by Davis et al. (2016). Upstream material and energy requirements, along with capital and operating costs (CAPX and OPX), were dynamically calculated based on primary modeling inputs, including facility size, productivity $\left(\mathrm{g} \mathrm{m}^{-2} \mathrm{day}^{-1}\right)$, algal strain characteristics, and nitrogen recycling from downstream processes. For the baseline HTL, protein extraction, and fractionation pathways, the facility size was set to 10,000 wetted acres (4047 ha), representing an upper limit to facility 
economies of scale and also avoiding significant sizing effects on downstream models. Productivity for these three models was set to $25 \mathrm{~g}$ ash free dry weight (AFDW) $\mathrm{m}^{-2} \mathrm{day}^{-1}$. Nutrients were provided by ammonia $\left(\mathrm{NH}_{3}\right)$ and diammonium phosphate (DAP), while $\mathrm{CO}_{2}$ was assumed to be purchased at $\$ 45$ per metric tonne (Davis et al., 2016).
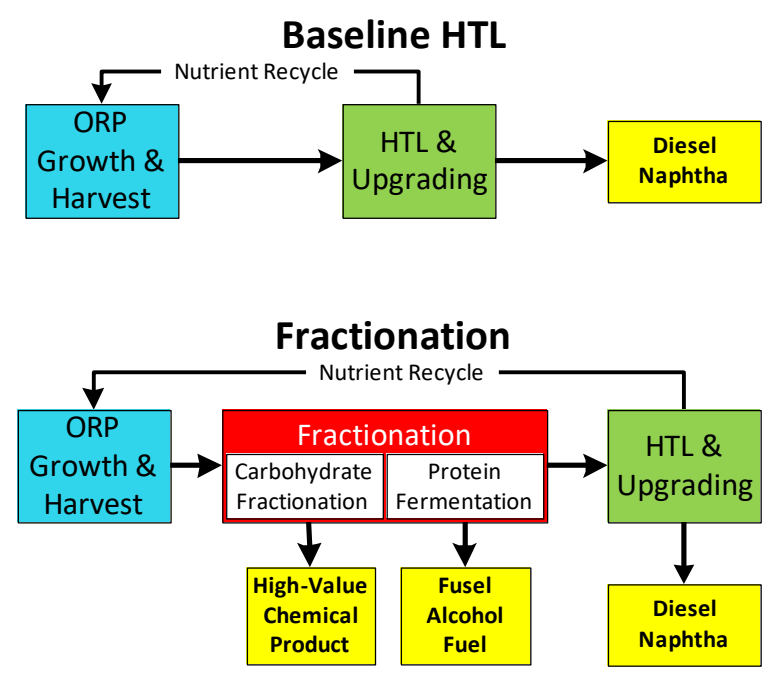

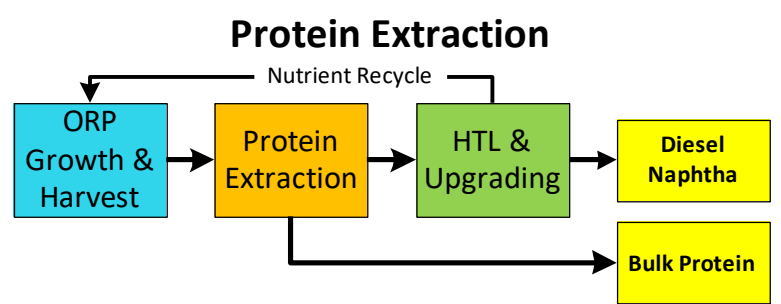

\section{First-of-a-Kind}

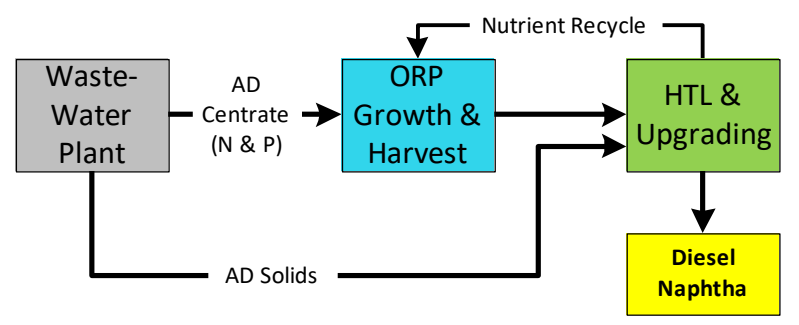

Figure 1: Process model diagrams for the four algal biofuel and co-product pathways examined in this study. The baseline HTL, protein extraction, and fractionation pathways utilized a common upstream ORP and three-stage dewatering model sized to 10,000 wetting acres. The first-of-a-kind pathway represents a smaller-scale (100 ha), first commercial deployment facility coupled to a wastewater treatment plant, utilizing centrate and solids from anaerobic digestion for supplemental nutrients and biomass for HTL.

Hydrothermal liquefaction: HTL models for all pathways were developed from Jones et al. (2014), with updated energy requirements for electricity, process heat, and annualized drying from Frank et al. (2016). Major mass flows modeled in each HTL sub-system include input biomass at $20 \%$ solids by weight, biocrude and biochar yields, an aqueous phase to catalytic hydrothermal gasification (CHG) for nitrogen recovery; and hydrogen flow to the hydrotreater and hydrocracker for biocrude upgrading to diesel and naphtha. Installed capital costs for each system component were scaled to these flows using the scaling factors listed in Jones et al. (2014), while catalyst costs were scaled directly. Yields from upgrading the biocrude were taken directly from Jones et al. (2014) as 69.1\% diesel and 13.6\% naphtha by weight. Nitrogen recovery for the entire HTL process was assumed to be $85 \%$ of the nitrogen in the input biomass. 
HTL biocrude and biochar yields were the major input parameters that changed between models. Biocrude yields are sensitive to biomass composition - the weight percentages of lipids, carbohydrates, protein, and ash. In this study, the predictive model developed by Li et al. (2017) was used to estimate the biocrude and biochar yields for the varying biomass compositions input to the HTL for each scenario. For the baseline HTL scenario, the biocrude yield was $50 \%$ of AFDW ( $0.5 \mathrm{~kg}$ biocrude per $\mathrm{kg}$ AFDW in), while biochar yield was estimated as $10 \%$ of dry weight (including ash).

Protein Extraction: The protein extraction pathway is a representative process in which only protein is extracted from the algae, leaving the lipids and remaining biomass for HTL processing into fuels. The protein extraction model was based on that from Gnansounou and Kenthorai Raman (2016), with performance and energy requirements developed from several lipid extraction models (Frank et al., 2011; Gnansounou and Kenthorai Raman, 2016; Mu et al., 2017; Quinn et al., 2014; Vanthoor-Koopmans et al., 2013). Capital costs for the protein extraction system were scaled from the lipid extraction costs from Davis et al. (2011) and Richardson et al. (2012). The extracted biomass is then processed using HTL, with an estimated biocrude yield of $60 \%$ of AFDW in and biochar yield of $14 \%$ of dry weight in (Li et al., 2017).

Fractionation: the fractionation scenario is a variation of the pathway developed by DeRose et al. (2018). For this study, the carbohydrate portion of the biomass is converted to a representative high-value chemical product, the protein portion is fermented into fusel alcohols (principally a blend of butanol isomers), and the remaining biomass is sent to HTL. The yield for the high-value chemical product was estimated by scaling down the by-weight yields reported for ethanol ( 2 carbons, $51.1 \%$ ) and fusel alcohols (4 carbons, 39\%). Assuming a 6-carbon molecule, the chemical yield was then set to $26.9 \%$. This value is consistent with the yields estimated by scaling molar yields of representative $C_{6}$ to $C_{13}$ compounds such as hydroquinone and fluorenol to that of ethanol (i.e., carbons evenly split between the compound and $\mathrm{CO}_{2}$, yielding $24-33 \%$ by weight). Capital and operating costs for the fractionation system are scaled directly from DeRose et al. (2018), including lower HTL heating requirements due to system heat integration. HTL biocrude and biochar yields on the remaining biomass were estimated to be 
$70 \%$ and $7 \%$, respectively. Nitrogen was available for recovery from the fusel alcohol fermentation stage in the form of struvite, an ammonium phosphate mineral usable as a fertilizer with an estimated selling price of $\$ 500$ ton $^{-1}$.

First-of-a-Kind: The FOAK scenario represents a small scale, first commercial deployment facility. One opportunity improve the economics of such a facility while also providing additional societal benefits is to couple algal biofuel production to a wastewater treatment plant (WWT). Many wastewater treatment plants utilize anaerobic digestion $(\mathrm{AD})$ to reduce the chemical oxygen demand and solids content of the treated streams. Influent wastewater undergoes preliminary treatment and settling to remove heavy solids, followed by additional mixing, clarification, and separation of activated sludge. The solids and sludge are thickened and sent to $\mathrm{AD}$, which produces biogas (methane), waste sludge, and an effluent centrate stream, which is high in dissolved nitrogen. Traditionally, the waste AD sludge undergoes further dewatering (through a belt filter press) and then must be hauled and disposed of. The centrate stream is recycled back into the facility, which increases operating costs of the system to reduce to nitrogen content. Coupling algal biofuel production to a wastewater facility can reduce the costs associated with these $\mathrm{AD}$ waste streams. Algae can utilize the dissolved nitrogen and phosphorus of the $\mathrm{AD}$ centrate as nutrient for growth, while the $\mathrm{AD}$ sludge can be combined with the algal biomass for direct HTL processing to increase fuel yields and reduce disposal costs.

Operations data for a 15 million-gallon-per-day (MGD) plant in Phoenix, AZ was provided by Pete Lammers (Arizona State University), shown in Table 1. Wastewater treatment costs were modeled by Jennifer Markham (National Renewable Energy Laboratory, Golden CO) using CAPDETWorks, an industry standard WWT design and costing software from Hydromantis that is continuously updated and validated with current field and operations data from across the U.S. This model provided cost estimations for the dewatering and disposal of the $\mathrm{AD}$ sludge, as well the decrease in operational costs associated with the removal of the AD centrate recycle stream from the WWT process. Together, these two process were estimated to contribute $\$ 760,000 \mathrm{yr}^{-1}$ in capital (i.e., belt filter press) and operational costs to the wastewater facility. 
Table 1: WWT data from 15 MGD plant in Phoenix, AZ

\begin{tabular}{|c|c|c|c|c|}
\hline \multicolumn{5}{|l|}{ Data from Phoenix WWT } \\
\hline AD Waste Streams & Low & Baseline & High & Units \\
\hline Nitrogen in AD centrate & 400 & 600 & 800 & $\mathrm{mg} / \mathrm{L}$ \\
\hline Phosphorus in $\mathrm{AD}$ centrate & 20 & 30 & 40 & $\mathrm{mg} / \mathrm{L}$ \\
\hline AD sludge production & 38 & 44 & 50 & g / capita / day \\
\hline \multicolumn{5}{|l|}{ Other Assumptions } \\
\hline Per capita wastewater generation & \multicolumn{3}{|c|}{150} & gal per day \\
\hline Population served by WWT & \multicolumn{3}{|c|}{100,000} & \\
\hline Centrate effluent flow & \multicolumn{3}{|c|}{$0.5-1 \%$} & of WWT influent \\
\hline
\end{tabular}

The baseline $\mathrm{AD}$ waste stream cases where utilized for modeling of the FOAK algal facility, namely: centrate as $1 \%$ of the WWT plant inflow containing $600 \mathrm{mg} \mathrm{N}$ and $30 \mathrm{mg}$ P per liter. AD sludge production was calculated at $4400 \mathrm{~kg} \mathrm{day}^{-1}$ (at $31 \%$ ash and $1.66 \% \mathrm{~N}$ ). Biocrude and biochar yields on the algae were assumed to be the same as for the baseline HTL scenario, while yields for the AD sludge were estimated at $10 \%$ AFDW and $20 \%$ of dry weight for biocrude and biochar, respectively (Pete Lammers). Given the demonstrative nature of the FOAK plant, algal productivity was set to a lower value of $20 \mathrm{~g} \mathrm{~m}^{-}$ ${ }^{2}$ day $^{-1}$. The algal production facility was scaled to utilize the entire nitrogen content of the AD centrate. With downstream nitrogen recycling from the conversion process, the algal facility size was then estimated at approximately 100 ha (247 acres). Triple superphosphate was used to meet additional algal P requirements. The algal facility was assumed to receive the avoided WWT cost credit of $\$ 760,000 \mathrm{yr}^{-1}$ for nitrogen removal form the centrate and disposal / reuse of the sludge. 


\subsubsection{Techno-Economic Analysis}

A baseline techno-economic analysis was performed for each scenario using the standard $\mathrm{n}^{\text {th }}$ plant assumptions from literature (Barlow et al., 2016; Davis et al., 2016, 2014; Summers et al., 2015). Primary $\mathrm{n}^{\text {th }}$ plant assumptions include a $10 \%$ internal rate of return (IRR, discount rate), 30 year facility lifespan, $8 \%$ interest on debt financing, and 35\% tax rate. Direct and indirect capital costs, along with the fixed operating costs for maintenance and insurance, were calculated from the installed equipment costs using the same percentages and process breakouts as presented in Davis et al. (2016) and Jones et al. (2014). Thus, costs associated with ponds, harvesting, other upstream equipment, and downstream conversion processes were calculated separately and then totaled. Labor costs for upstream and downstream processes were scaled from Davis et al. (2016) and Jones et al. (2014). Capital, labor, and chemical costs were updated to a cost year of 2014 using the respective indices listed in Schwab (2016). A complete detail of all costs and assumptions is presented in the supplementary information. Capital costs, operational costs, system yields, and these foundational economic assumptions were used to perform a 30-year discounted cash flow rate of return (DCFROR) for each scenario. Using the IRR as the discount rate, the minimum biofuel selling price (\$ per gge) was calculated to give a net present value (NPV) of zero for the system. This value represents the levelized cost of the biofuel over the life of the facility to support a $10 \%$ IRR.

\subsection{TEA Methodology Sensitivity}

Engineering process models with detailed mass and energy balances were developed for multiple algal biofuel pathways. These engineering process models were constructed modularly to the support the evaluation of different pathways and were foundational for establishing baseline TEA results.

\subsubsection{Co-Product Prices}

Co-products represent potentially important sources of revenue for algal biofuel systems. However, while biofuel selling price is dynamically calculated using TEA, the value of co-products is generally specified upfront. Sensitivity of the biofuel price to assumed co-product selling prices is thus an 
important consideration for algal systems analysis. For the protein extraction and fractionation pathways in this study, baseline co-product selling prices were used for initial results, and a sensitivity was performed to examine the impact of higher or lower co-product prices. For the protein extraction pathway, protein selling prices were estimated from the value of crude protein in animal feeds such as corn, corn gluten, soybean meal, and distiller's grains - i.e., the cost per kg of protein in each feed. From these, a baseline protein price of $\$ 1 \mathrm{~kg}^{-1}$ was selected (Shewmaker et al., 2013). Sensitivity of results to a higher selling price of $\$ 1.5 \mathrm{~kg}^{-1}$ protein (possibly targeting human consumption) and a lower value of $\$ 0.5$ $\mathrm{kg}^{-1}$ (for potentially reduced quality) was examined. Additionally, HTL biochar was considered to have potential market value as a fertilizer or soil amendment, and theoretical biochar selling prices of $\$ 100$ and $\$ 500$ ton $^{-1}$ were examined for all algal biofuel pathways.

For the fractionation process, the representative high-value chemical product was assumed to have a selling price similar to compounds such as succinic acid or hydroquinone. For this study, a baseline product price of $\$ 3 \mathrm{~kg}^{-1}$ was assumed. Sensitivity examined alternative prices of $\$ 1, \$ 2$, and $\$ 4$ $\mathrm{kg}^{-1}$, corresponding to price ranges for bulk succinic acid $\left(\$ 1-\$ 3 \mathrm{~kg}^{-1}\right)$ or hydroquinone $\left(\$ 4-\$ 6 \mathrm{~kg}^{-1} \mathrm{or}\right.$ more) (Alibaba Group, 2018). The production and sale of struvite from the fusel alcohol fermentation step was also examined, with struvite assumed to be valued at $\$ 500$ ton $^{-1}$ (DeRose et al., 2018).

\subsubsection{Public Policies}

The baseline TEA models were leveraged to understand the impact of including similar benefits from public policies used in the deployment of corn ethanol starting in the 1970s and cellulosic fuels in the 2000s. For this analysis, these policies included production subsidies, faster depreciation rates, and federally supported reduced loan rates (Amanor-Boadu et al., 2014; Hise et al., 2016; Solomon et al., 2007; Yacobucci, 2008).

Between 1978 and 2013, corn ethanol producers received production subsidies (as excise or blender tax credits) of $\$ 0.40-0.60 \mathrm{gal}^{-1}$ (Solomon et al., 2007; Tyner, 2015). More recently, other biofuels have received similar subsidies, including cellulosic ethanol (\$1.01 $\mathrm{gal}^{-1}, 2008$ - 2017), bio- and renewable diesel ( $\$ 1 \mathrm{gal}^{-1}, 2005$ - 2017), and algal fuels as separate category of second generation fuels 
(\$1.01 $\mathrm{gal}^{-1}, 2013$ - 2017) (U.S. DOE Alternative Fuels Data Center, 2018). However, given the unlikelihood of production subsidies existing for the entire 30-year lifespan of algal biofuel facilities, the impacts of several subsidy levels $(\$ 0.5, \$ 1$, and $\$ 2$ per gallon) were examined for the range of shorter subsidy lengths. Following the method used by Amanor-Boadu et al. (2014), it was assumed that the fuel is sold to a blender so that the algal production facility can extract the full value of the subsidy (i.e., the blender uses the full subsidy as a tax credit, and is thus able to pay the subsidy value more for the algal fuels).

For depreciation, the analysis examined schemes both shorter and longer than the 7-year MACRS used by the $\mathrm{n}^{\text {th }}$ plant assumption. Faster depreciation schemes used for ethanol plants were considered, including 5-year MACRS and special depreciation of 50\% in Year 1 (used by cellulosic ethanol plants from 2012 - 2017) (U.S. DOE Alternative Fuels Data Center, 2018). The impact of longer deprecation schemes was also examined, including 20-year MACRS and linear deprecation schemes up to 30 years in length (the assumed plant lifespan). The final policy support considered here was federally guaranteed loan programs, which reduce the loan interest rates. The Department of Energy Title XVII Loan program supporting renewable energy projects, including biofuels, frequently gave interest rates in the $4-6 \%$ range, which was considered here (Federal Financing Bank, 2018). Additionally, the benefit of the new lower corporate tax rate of $21 \%$, down from $35 \%$ was assessed. The individual impact of each of these alternative policies or TEA assumptions was separately evaluated for the algal biofuel pathways in this study.

\subsubsection{Carbon Price Policy}

The environmental impact of algal biofuel pathways is evaluated using LCA. A primary metric of consideration for biofuels is Global Warming Potential (GWP), which is a measure of the greenhouse gas (GHG) emissions associated with the process. While this metric has a required target to meet the Renewable Fuel Standard (RFS), it is otherwise traditionally evaluated separately from TEA, leaving little incentive for additional emissions reductions beyond the RFS target. One means of connecting LCA with TEA results is through the introduction of a carbon price, or a cost on the GHG emissions from a process. 
Connecting a carbon price to a TEA requires an accurate LCA for each algal biofuel pathway in this study. Total life cycle emissions were calculated from the mass and energy balances in the engineering process model using life cycle inventory (LCI) data for each flow. Each LCI reported associated emissions of carbon dioxide, methane, and dinitrogen monoxide, which were normalized on a $\mathrm{CO}_{2 \text {-equialent }}$ $\left(\mathrm{CO}_{2 \text {-eq }}\right)$ basis using the IPCC 100-year global warming equivalency factors for each emission type of 1 , 34, and 298, respectively. LCI data for fertilizer inputs were taken from GREET (Argonne National Laboratory, 2017), while $\mathrm{CO}_{2}$ delivery was assumed at $15.1 \mathrm{~g} \mathrm{CO}_{2-\mathrm{eq}} \mathrm{kg}^{-1} \mathrm{CO}_{2}$ (Davis et al., 2016; Frank et al., 2016). The LCI for electricity was assumed to be $600 \mathrm{~g} \mathrm{CO}_{2 \text {-eq }} \mathrm{kWh}^{-1}$ based on a U.S. grid energy mix, while that for natural gas was estimated at $60 \mathrm{~g} \mathrm{CO}_{2 \text {-eq }} \mathrm{MJ}^{-1}\left(10 \mathrm{~g} \mathrm{CO}_{2 \text {-eq }} \mathrm{MJ}^{-1}\right.$ for production and 50 $\mathrm{g} \mathrm{CO}_{2 \text {-eq }} \mathrm{MJ}^{-1}$ for combustion). Carbon credits were considered for carbon stored in the fuel and coproducts, and were calculated from the carbon content of each. Combustion emissions were set equal to the carbon credit of the fuel. GWP was calculated on both a well-to-pump (WTP) and well-to-wheels (WTW) basis, which excludes or includes combustion emissions, respectively.

The economic impact of these process emissions was evaluated by including carbon pricing schemes in the TEA for each algal biofuel pathway. The four social cost of carbon scenarios from Interagency Working Group on Social Cost of Carbon (2016) were used. In these four scenarios (known as the $5 \%, 3 \%, 2.5 \%$, and high impact scenarios), the estimated economic impact per ton of $\mathrm{CO}_{2}$ emitted increases with time, representing greater economic damages for future emissions. In this study, all fuel production was assumed to begin in year 2020 and continue through 2050 (the 30-year lifespan for standard TEAs). The carbon prices, reported on 5-year intervals, were updated from 2007 to 2014 dollars using the discount rates for each cost scenario model (5\%, 3\%, 2.5\%, and 3\%), with linear interpolation used to determine the yearly values between those reported. For simplicity, only the $\mathrm{CO}_{2}$ prices were considered, with other GHG emissions normalized to $\mathrm{CO}_{2 \text {-eq }}$ values. Thus, the resultant carbon prices for each social cost scenario increased from $\$ 17, \$ 52, \$ 74$, and $\$ 151$ ton $^{-1} \mathrm{CO}_{2}$ to $\$ 36, \$ 85, \$ 113$, and $\$ 261$ $\operatorname{ton}^{-1}$ over the 30-year timespan for the 5\%,3\%, 2.5\% and high impact scenarios, respectively. The economic impact on the algal biofuel pathways was then compared to that of fossil diesel and first- 
generation corn ethanol. The emissions associated with diesel and corn ethanol production were taken from GREET as 18 and $58 \mathrm{~g} \mathrm{CO}_{2 \text {-eq }} \mathrm{MJ}^{-1}$, respectively (Argonne National Laboratory, 2017). Combustion emissions for all fuels were estimated by their carbon content, calculated as $75 \mathrm{~g} \mathrm{CO}_{2 \text {-eq }} \mathrm{MJ}^{-1}$ for fossil diesel, $71 \mathrm{~g} \mathrm{CO}_{2 \text {-eq }} \mathrm{MJ}^{-1}$ for corn ethanol, and $73 \mathrm{~g} \mathrm{CO}_{2 \text {-eq }} \mathrm{MJ}^{-1}$ for algal fuels. For comparison, the price impact on fossil diesel and corn ethanol was levelized to a net present value in $\$ \operatorname{gge}^{-1}$ using a simplified 30-year cashflow, with the same baseline TEA assumptions as for algal fuels. Baseline selling prices for fossil diesel and corn ethanol were set to the target of $\$ 3 \mathrm{gge}^{-1}$. As with the LCA, fuel pathways were evaluated on both a WTP and WTW basis, with credits for carbon in biofuels (including corn ethanol) and sequestered in co-products.

\subsection{Defining Economic Viability}

Biofuel economic models were leveraged to assess the cost tradeoffs and other improvements required for algal fuels to become viable and cost competitive with existing fuel pathways (reaching the $\$ 3$ gge $^{-1}$ target set by the Department of Energy). Trends in the results from TEA methods were examined to better understand the impact of different cost types and modeling assumptions. Correlations were used to compare algal fuels to existing biofuel processes to identify feasible algal pathway improvements.

\subsubsection{Tradeoff Between $C A P X$ and $O P X$}

Foundational TEA methods were used to investigate the relationship between CAPX, OPX, and overall fuel selling price results, particularly the tradeoff between cost types. This relationship was generalized to be representative of any type of biofuel production system (corn, cellulosic, or algae) by determining the breakeven revenue requirement - i.e., the yearly process revenue required for a system NPV of 0 . For a biofuel system, this revenue is equivalent to the TEA result in $\$$ gge $^{-1}$ multiplied by the yearly fuel production. A generic TEA model utilizing standard economic assumptions was developed to calculate the breakeven revenue requirement across a range of CAPX and OPX cost combinations. Based on the costs presented in previous algal studies, CAPX costs of $\$ 0-\$ 3$ billion and OPX costs of $\$ 0$ \$250 million per year were examined, with required revenue calculated for each set of CAPX and OPX 
costs. The tradeoff between CAPX and OPX was then developed by evaluating the impact on required revenue due to changes in each cost. CAPX and OPX costs were independently varied by $\$ 1-\$ 10$ million, with the impact normalized to a required revenue per cost basis. These relationships were used to establish a correlation between CAPX $(\$)$, OPX $\left(\$ \mathrm{yr}^{-1}\right)$, and breakeven revenue $\left(\$ \mathrm{yr}^{-1}\right)$. The sensitivity of these correlations to TEA assumptions was evaluated, which included: OPX type (fixed versus variable costs), facility size, IRR; loan rate, tax rate, equity versus loan ratio, and depreciation type.

\subsubsection{Comparison to Corn Ethanol}

The tradeoffs between CAPX and OPX were used to establish a metric to compare algal fuels to corn and cellulosic ethanol. Current and historic production and capital cost estimates for corn ethanol were gathered from literature sources (Hettinga et al., 2009; Irwin, 2018; Kane and Reilly, 1989; McAloon et al., 2000; Shapouri and Gallagher, 2005; Solomon et al., 2007; Whims, 2002). Those for cellulosic ethanol were taken from cost models (Humbird et al., 2011; McAloon et al., 2000; Solomon et al., 2007; Zhao et al., 2015) and estimates for current operation of six real-world plants (Yu et al., 2016). Established algal fuel downstream models for HTL and combined algal processing (CAP, a specific fractionation design) were taken from Davis et al. (2014), Jones et al. (2014), and Schwab (2016), and upstream-downstream cost models for both technologies were created by combining Schwab (2016) with Davis et al. (2016). All fuel production was harmonized to a gge basis, and all costs were normalized by yearly fuel production to remove plant size variation. Capital costs were thus compared on a $\$ \mathrm{gge}^{-1} \mathrm{yr}^{-1}$ basis (Equation 1), while total operating costs were compared by $\$ \operatorname{gge}^{-1}$ (Equation 2). Co-product credits were calculated on the same basis as OPX $\left(\$ g g g e^{-1}\right)$ and subtracted from the total to calculate net OPX. Improvements suggested by these comparisons were integrated into the baseline algal TEA models to assess their impact on the economic viability of the biofuels.

$$
\begin{aligned}
& \text { Relative CAPX }\left(\$ g g e^{-1} y r^{-1}\right)=\frac{\$ C A P X}{g g e / y r} \\
& \text { Relative OPX }\left(\$ g g e^{-1}\right)=\frac{\$ O P X / y r}{g g e / y r}
\end{aligned}
$$




\section{Results \& Discussion}

Mass and energy balances from the engineering process models were used to perform TEAs on the four algal biofuel production pathways. The sensitivity of results to modeling assumptions was evaluated for varying co-product prices, benefits from public policies, and carbon pricing schemes. A correlation was developed for the tradeoff between capital and operating costs and with the required process revenue. Sensitivity of this correlation was tested against the range of TEA assumptions to identify important methodology considerations. The results were leveraged to compare algal pathways to corn and cellulosic ethanol to support recommendations to make algal fuels cost competitive with these established technologies.

\subsection{Multiple Pathway Economic Viability}

A baseline TEA was conducted for each of the algal biofuel scenarios in this study. The minimum biofuel selling prices were calculated from 30-year DCFROR analysis, Figure 2. Contributions of each cost type (upstream and downstream capital costs, operational costs, etc) to the total selling price were calculated by the ratio of net present value of each cost to that of the total, based on an IRR of $10 \%$. The baseline HTL scenario has the lowest overall production cost at $\$ 5.37 \mathrm{gge}^{-1}$. Production costs (i.e., capital and operating costs, before credits) for the protein extraction and fractionation pathways are higher, at $\$ 7.11$ and $\$ 7.77 \mathrm{gge}^{-1}$, respectively. These higher production costs are primarily from lower fuel production due to the diversion of biomass to co-products - both processes see a minor decrease in total CAPX compared to the baseline HTL, as the addition of the co-product equipment costs is offset by lower HTL costs. Significant co-product credits of $\$ 2.67$ and $\$ 3.46 \mathrm{gge}^{-1}$ offset these higher production costs and lead to lower overall fuel costs of $\$ 4.44$ and $\$ 4.31 \mathrm{gge}^{-1}$ for the protein extraction and fractionation pathways, respectively. For all three pathways, upstream costs associated with biomass production represent about $60 \%$ of the overall fuel cost. As expected, biomass production represents a dominate cost driver for these algal systems.

The FOAK plant sees much higher fuel price from lower productivity, significant plant size effects, particularly from downscaling the HTL system CAPX, and higher fixed costs for labor and 
maintenance. Though the algal system receives a wastewater treatment credit, this credit fails to offset the cost increases due to size, leading to a fuel price of $\$ 11.13 \mathrm{gge}^{-1}$. The lower productivity was found to account for $\$ 1.30 \mathrm{gge}^{-1}(23 \%)$ of the increase over the baseline HTL result, while the smaller plant scale accounts for the other $\$ 4.46 \mathrm{gge}^{-1}(77 \%)$. The inclusion of the wastewater sludge was found to slightly increase costs due to higher mass flows and low fuel production in the HTL process. Removing the sludge and resizing the equipment was found to save $\$ 0.02 \mathrm{gge}^{-1}$, corresponding to a fuel price of $\$ 11.11$ gge $^{-1}$. Even with $\mathrm{n}^{\text {th }}$ plant TEA assumptions, the FOAK system has dramatically higher fuel costs due to its small size.

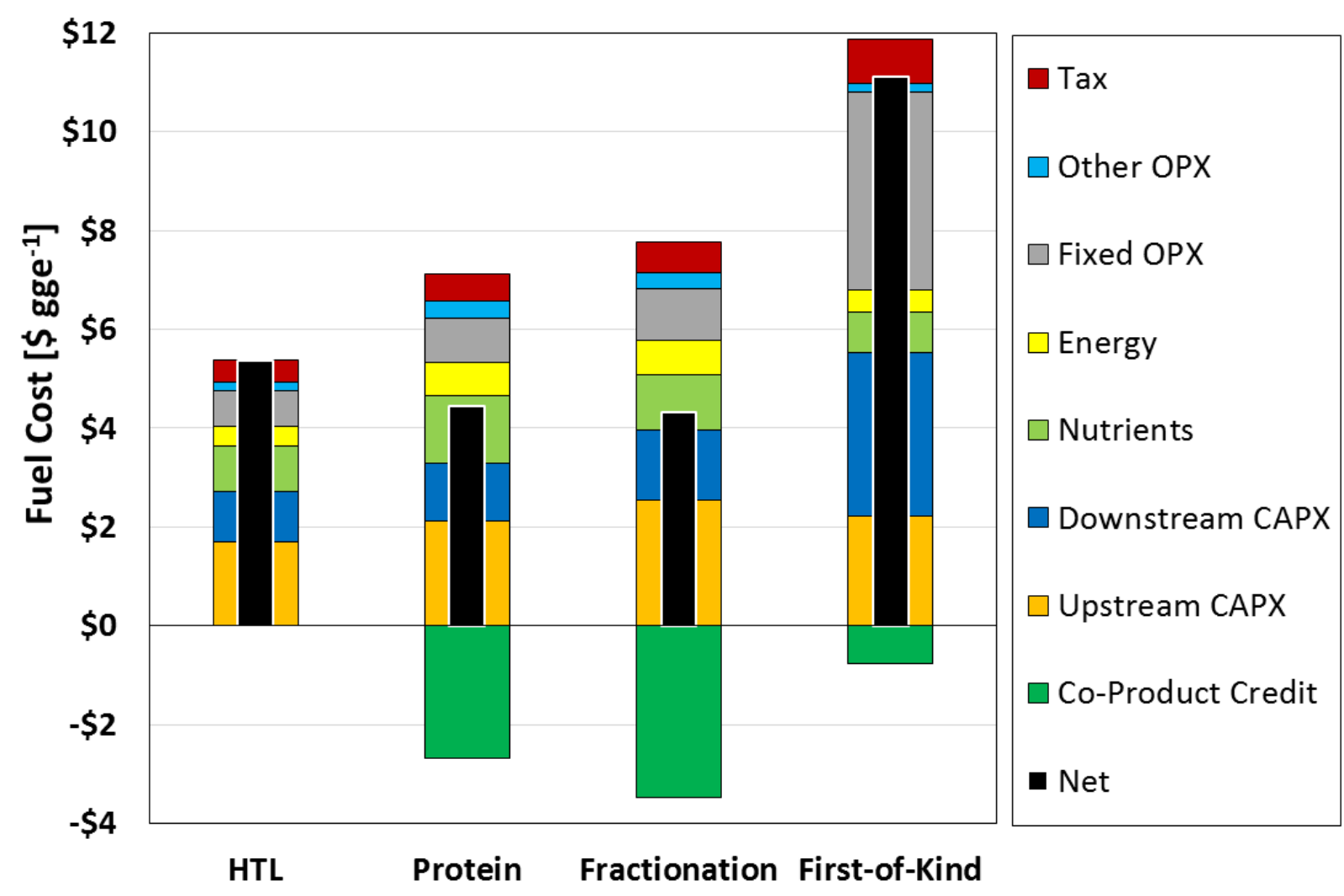

Figure 2: Baseline TEA results for the four models developed for this study, with contributions by each cost type. The standard HTL pathway has the lowest overall costs $\left(\$ 5.37 \mathrm{gge}^{-1}\right)$, but the credits for the protein extraction and fractionation pathways offset their higher CAPX and OPX costs sufficiently to result in lower overall fuel costs (\$4.44 and $\$ 4.31 \mathrm{gge}^{-1}$, respectively). These higher CAPX and OPX costs are primarily attributed to lower fuel production from biomass diversion to co-products. The water treatment credit for the first-of-a-kind plant fails to sufficiently offset the impact of the smaller facility size, especially for the downstream conversion process CAPX and fixed costs, leading to fuel costs of $\$ 11.13$ gge $^{-1}$. 
The baseline HTL costs from this study are somewhat higher than those reported in Jones et al. (2014) and Schwab (2016), which reported fuel costs of $\$ 4.51$ and $\$ 4.72 \mathrm{gge}^{-1}$, respectively. These differences are attributed entirely to modeling assumptions. The HTL biocrude yield for this study was decreased from 59\% to 50\% AFDW, to be more consistent with the yield estimates from Li et al. (2017) that were used for the protein extraction and fractionation scenarios. Additionally, Jones et al. (2014) uses the equivalent of biomass grown at $30 \mathrm{~g} \mathrm{~m}^{-2} \mathrm{day}^{-1}$, compared to the $25 \mathrm{~g} \mathrm{~m}^{-2} \mathrm{day}^{-1}$ assumed by this study, further decreasing overall fuel production. Finally, there is proportionally more flow through the HTL system in this study, as biomass concentration was assumed to be $20 \%$ by weight for all scenarios, whereas Jones et al. (2014) assumes $20 \%$ AFDW, which is closer to $22 \%$ by weight with ash included. The production costs (before credits) from the protein extraction and fractionation pathways are comparable to those reported by DeRose et al. (2018). Contributions from upstream biomass production to the total fuel cost was about $60 \%$ for all three pathways, slightly lower than the $70-80 \%$ reported in other studies (Barlow et al., 2016; Davis et al., 2014; Jones et al., 2014; Schwab, 2016). Results from the first-of-a-kind plant are comparable to the those reported for similar smaller scale plants $(\$ 8.18-\$ 12.11$ $\mathrm{gal}^{-1}$ of biocrude) (Beal et al., 2015). These comparisons show that the modeled scenarios and results developed in this study are consistent with previous efforts.

\subsection{TEA Methodology Sensitivity}

The economic models were used to examine the impact of methodology and economic assumptions on the baseline results. Scenarios encountered in real world implementation were evaluated, including sensitivity to co-product prices, public policies and alternative TEA assumptions, and carbon pricing schemes.

\subsubsection{Co-Product Prices}

The protein extraction and fractionation pathways have higher CAPX and OPX costs compared to the baseline HTL. These costs are offset by significant credits from co-products. For the former, protein at $\$ 1 \mathrm{~kg}^{-1}$ provides a $\$ 2.67 \mathrm{gge}^{-1}$ credit and results in a net fuel price of $\$ 4.44 \mathrm{gge}^{-1}$ (Figure 2). The fuel 
price, however, is extremely sensitive to the value of this credit. Lower and higher protein prices $(\$ 0.5$ and $\$ 1.5 \mathrm{~kg}^{-1}$ ) directly scale this credit (to $\$ 1.34$ and $\$ 4.01 \mathrm{gge}^{-1}$ ), changing the final fuel price to $\$ 5.77$ and $\$ 3.10$ gge $^{-1}$, respectively. The same dynamic is observed for the fractionation pathway. The baseline high-value chemical product price of $\$ 3 \mathrm{~kg}^{-1}$ provides a $\$ 3.46 \mathrm{gge}^{-1}$ credit, for a net fuel price of $\$ 4.31$ $\operatorname{gge}^{-1}$ (Figure 2). Alternative chemical product prices of $\$ 1, \$ 2$, and $\$ 4 \mathrm{~kg}^{-1}$ scale this credit to $\$ 1.5, \$ 2.31$, and $\$ 4.61$, for net fuel prices of $\$ 6.62, \$ 5.47$, and $\$ 3.16 \mathrm{gge}^{-1}$, respectively. The production and sale of struvite from the fractionation process can provide an additional $\$ 0.27$ credit. This credit is more valuable to the process economics than recycling struvite to the algal growth process to decrease fertilizer costs (which contribute $\$ 0.13 \mathrm{gge}^{-1}$ ). Additionally, the sale of HTL biochar at $\$ 100$ ton $^{-1}$ provides credits of $\$ 0.08, \$ 0.08, \$ 0.03$, and $\$ 0.12$ respectively for the baseline HTL, protein extraction, fractionation, and FOAK pathways. This credit scales up directly with biochar price, thus increased biochar value will further benefit pathway economics. Altogether, these assumptions regarding co-product prices can have a several \$ gge ${ }^{-1}$ impact on overall TEA results and biofuel selling price.

This sensitivity of fuel price to co-product prices highlights important considerations that have not received sufficient attention in literature. First, diesel at $\$ 3 \mathrm{gge}^{-1}$ is approximately equivalent to $\$ 1 \mathrm{~kg}^{-}$ ${ }^{1}$, so any co-product that decreases overall fuel yield should be worth this value or greater. Moreover, given the challenge of fuel-only pathways to reach the $\$ 3 \mathrm{gge}^{-1}$ target, lower value co-products in the $\$ 1$ to $\$ 2 \mathrm{~kg}^{-1}$ range should instead aim to compliment fuel production. Higher value co-products may be less sensitive to overall fuel production volume, but changes in these co-product prices can have major impacts on the economics of the system. As the value of many of these potential chemical and pharmaceutical products may be dependent on market dynamics, the inclusion of these alternative prices in TEA models of new algal pathways is paramount to realistically representing the economics of the system. Additionally, awareness of market sizes for potential products is important for the planning of these large-scale systems. Pathway economic viability that is dependent on a high-value product with a small market size does not represent a sustainable large-scale solution. 


\subsubsection{Public Policies}

Many of the public policies considered here alter TEA assumptions from the $\mathrm{n}^{\text {th }}$ plant standard.

Depreciation schemes increase or decrease the taxable lifespan of the facility, while federally guaranteed loans decrease loan interest rates. Fuel subsidies, especially as a blender tax credit, can be passed up the production chain as a revenue or cost offset to algal fuel producers. The impact on the baseline fuel price from alternative depreciation schemes or subsidies depends on their duration, as seen in Figure 3. Three depreciation scheme types (MACRS, and linear with and without special 50\% depreciation in the first year) and three subsidy levels $\left(\$ 0.5, \$ 1\right.$, and $\left.\$ 2 g \mathrm{ge}^{-1}\right)$ were considered for time periods over the lifespan of the plant. The impact of lower interest rates from federally guaranteed loans (of $4 \%$ to $6 \%$ ) and of the new lower federal tax rate $(21 \%)$ was also examined.
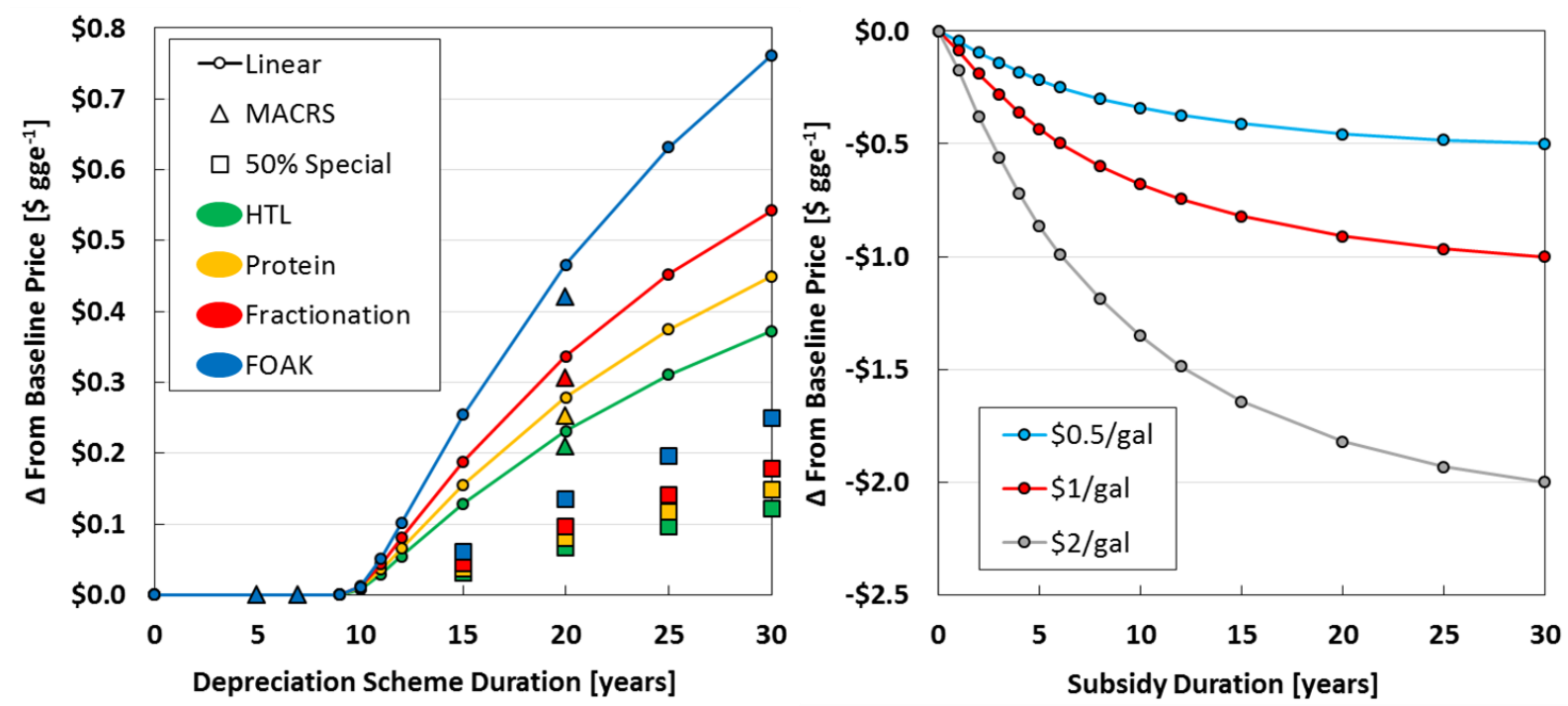

Figure 3: The impact of depreciation scheme duration, left, and short-term production subsidies, right, on fuel selling price. For depreciation, the scheme length and type (MACRS and linear with or without 50\% special depreciation) has no impact on fuel price so long as all capital costs are written off by Year 9 (7year MACRS is the standard for $n^{\text {th }}$ plant assumptions). Longer depreciation schemes increase the fuel cost, the magnitude of which is dependent on the relative scale of capital costs to fuel production (\$CAPX per gge/yr). HTL has both the lowest relative capital cost and fuel price increase from longer depreciation schemes, while the first-of-a-kind plant has the largest of both. Special 50\% depreciation has significant benefits for these longer depreciation schemes. Alternatively, even short-term subsidies can lead to significant fuel cost decreases, with much of the impact captured by subsidies much shorter than the lifespan of the facility. A 6-year subsidy captures $50 \%$ of the subsidy value as an equivalent fuel price decrease, while nearly $75 \%$ of the subsidy value is captured for a 12-year subsidy. Both scenarios demonstrate that earlier costs and benefits have a greater impact on results than those later on. 
For these systems, the depreciation scheme was found to have no impact on the overall fuel cost, so long as everything is written off before Year 10 (i.e., 9-year schemes or shorter). In the cashflow accounting, the deprecation charge is subtracted from the net revenue to calculate taxable income, and tax losses are forwarded each year. Because of this forwarding of losses, these systems have no net positive taxable income until Year 10. As such, there is no difference whether the write-off occurs entirely upfront or is divided between the first 9 years. Depreciation schemes longer than 9 years result in an increase in the relative cost of capital by lengthening the time required for write-off. The depreciation charge is smaller, so systems reach a net positive taxable revenue earlier, starting in Year 6 for a 10-year linear scheme and in Year 1 for a 30-year scheme. Because of discounting, costs and benefits in earlier years are worth significantly more than those later on. Longer depreciation schemes not only increase the total amount of taxes paid, but also weights more heavily those paid earlier.

The resulting cost increases from longer depreciation schemes are different for each model. The increase is directly related to the relative scale of CAPX to fuel production. The baseline HTL pathway has the lowest relative capital cost $\left(\$ 23 \mathrm{gge}^{-1} \mathrm{yr}^{-1}\right.$, from Equation 1), and likewise the lowest cost increases from longer deprecation schemes. In comparison, the first-of-a-kind plant has the highest relative capital $\operatorname{cost}\left(\$ 46 \mathrm{gge}^{-1} \mathrm{yr}^{-1}\right)$ and largest cost increases. Alternative depreciation schemes that accelerate the writeoff upfront reduce the cost increases from longer linear schemes. A 20-year MACRS only saves $\$ 0.02-$ $0.05 \mathrm{gge}^{-1}$ over the 20 -year linear scheme. However, special depreciation, with a $50 \%$ depreciation in the first year, leads to significant lower cost increases over pure linear schemes (up to $\$ 0.25-0.51 \mathrm{gge}^{-1}$ for 30-year linear schemes, or a $67-76 \%$ lower impact). Altogether, these results show that for this type of TEA analysis, depreciation schemes faster than 9 years are irrelevant. Changes to the $\mathrm{n}^{\text {th }}$ plant 7 -year MACRS assumption only matter if they lengthen the write-off beyond this point, but the impact of longer schemes can be significant.

Subsidies can provide significant benefit to the fuel price, even for short-term programs lasting only a few years (Figure 3). A subsidy program lasting only 6 years can capture $50 \%$ of the subsidy value as a fuel cost decrease - that is, a $\$ 1 \mathrm{gge}^{-1}$ subsidy for only 6 years of the plant life decreases the overall 
fuel price by $\$ 0.5$ over the life of the plant. A 12 -year subsidy captures almost $75 \%$ of the value as fuel price decreases (i.e., $\$ 0.75$ per $\$ 1 \mathrm{gge}^{-1}$ subsidy). As with depreciation, this result comes from the timeweighting effect of discounting in the TEA model, which gives earlier costs and benefits significantly greater impact on the overall results than those that occur later. Given the unlikelihood of public support for permanent, multi-decade subsidies (as received by corn ethanol), these results suggest that even shortterm subsidies can be an important component of establishing new technologies and rolling out production plants, providing temporary support for scale-up and cost decreases from learning.

Other real-world changes to standard TEA assumptions include alternative loan and tax rates. Guaranteed loans are a major component of federal support for emerging fuel technologies, and often have interest rates in the $4 \%-6 \%$ range. As with depreciation, the relative scale of capital costs determines the impact of lower loan rates. The baseline HTL has the lowest cost decreases, of $\$ 0.38$, $\$ 0.29$, and $\$ 0.19 \mathrm{gge}^{-1}$ for loan rates of $4 \%, 5 \%$, and $6 \%$, respectively, due to its lowest relative capital cost. The first-of-a-kind plant, as the most capital intensive, sees the most benefit, of $\$ 0.80, \$ 0.60$, and $\$ 0.40 \mathrm{gge}^{-1}$ for these rates. The protein extraction and fractionation pathways fall in the middle of these ranges. For taxes, the new federal rate of $21 \%$ (down from the $35 \%$ used by the $\mathrm{n}^{\text {th }}$ plant) decreases overall fuel costs by $\$ 0.21-0.43$ gge $^{-1}$, with greater cost reductions for scenarios with higher overall production costs (thus, HTL again sees the lowest cost reduction). Together, lower loan and tax rates are beneficial to algal fuels, though these benefits decrease as costs approach $\$ 3$ gge $^{-1}$. Thus, neither is likely to be a significant driver of economic viability in these TEA analyses and instead support the deployment of first-of-a-kind plants.

\subsubsection{Carbon Price Policy}

The environmental impact of a biofuel process can be coupled with TEA through the inclusion of a carbon price. A standard LCA was used to determine the GWP, normalized to a $\mathrm{CO}_{2 \text {-eq }}$ basis, of the algal biofuel pathways in this study. The WTP emissions of the baseline HTL, protein extraction, fractionation, and FOAK pathways were found to be $-44,-57,-29$, and $-51 \mathrm{~g} \mathrm{CO}_{2-\mathrm{eq}} \mathrm{MJ}^{-1}$, respectively. With fuel combustion emissions included, the WTW GWP of each scenario was 29, 15, 43, and $22 \mathrm{~g} \mathrm{CO}_{2 \text {-eq }} \mathrm{MJ}^{-1}$, 
respectively. These results, along with the GWP for fossil diesel and corn ethanol, were integrated into the TEA using four social cost of carbon (SCC) scenarios. The price changes of each pathway for the SCC scenarios are shown in Figure 4. The cost of emissions associated with fuel production and combustion and the credits for carbon capture were calculated separately to demonstrate the price impacts at different points in the production chain. For the consumer (fuel user), carbon prices increase the cost for all fuels due to the process and combustion emissions (i.e., a well-to-wheels system boundary), with fossil diesel increasing the most. Corn ethanol and algal pathways receive offsets from carbon capture credits for co-products, while the combustion emissions are canceled by the credit for the carbon in the fuel (as this carbon was assumed to be originally atmospheric).

The fuel consumer is assumed to pay the combustion emissions charge at the pump, regardless of the fuel source. Alternatively, for the algal and corn biofuel production facilities, carbon prices are seen instead on a well-to-pump basis. Thus, while the facility is charged for process emissions, carbon credits for co-products and fuels not only offset this cost, but can also decrease the net fuel production price. The combustion charge paid by the fuel user can be passed back to the algal fuel producer for the carbon credit, becoming essentially a production subsidy. However, as noted by Connelly et al. (2015), it is crucial that the carbon source for algal growth be counted as biogenic by both the LCA and the carbon price system. Sources of $\mathrm{CO}_{2}$ from flue gas or fossil deposits would need to be taxed prior to usage in the algal process, to render them as atmospheric for carbon credit purposes. Nevertheless, these results suggest that carbon capture credits can play a role in the future viability of algal pathways. 


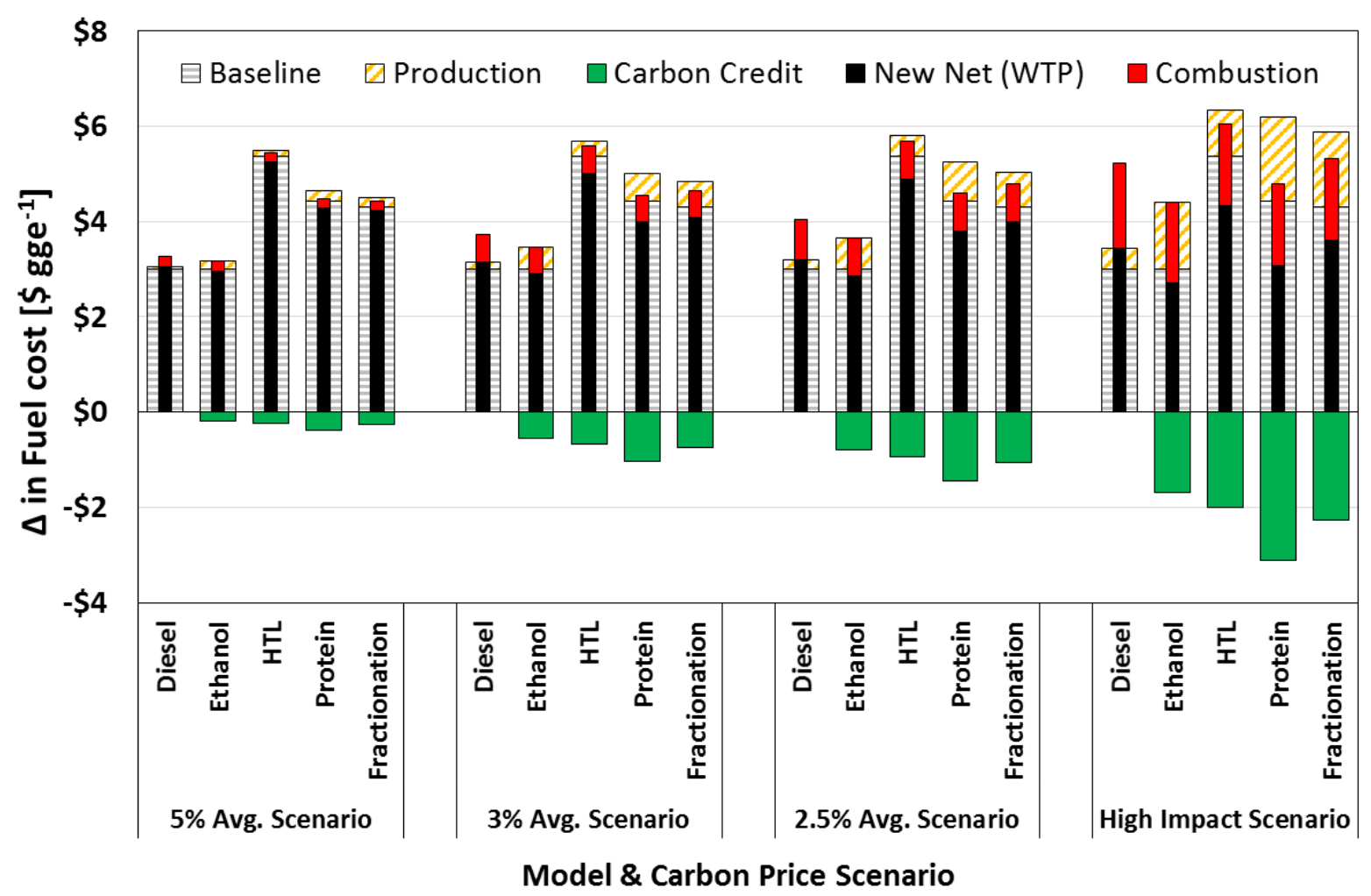

Figure 4: Change in fuel selling price for diesel, corn ethanol, and the three algal biofuel pathways, for the four social cost of carbon scenarios. A carbon price is applied to emissions associated with the production (orange hashed bar) and combustion / use (red solid bar), while biogenic carbon stored in products is treated as an offset credit (green). The carbon credit for the fuel is equal to the combustion charge. On a well-to-wheels basis (for a fuel consumer, the black plus red bars), a carbon price increases the cost of all fuels over the baseline (grey hashed bar). However, on a well-to-pump basis (i.e., for only the algal fuel production facility), the carbon credits actually decrease the overall cost of fuel. In this scenario, the combustion charge paid by the consumer is passed back up the production chain to the algal fuel producer.

\subsection{Defining Economic Viability}

TEA models were used to explore the impact of assumptions and methods on trends in results. A tradeoff correlation between CAPX, OPX, and process revenue was established and tested across these assumptions. This correlation provided a metric for comparing the algal biofuel pathways in this study to established corn and cellulosic ethanol pathways. From this comparison, observations were made about strategies for algal pathway improvement, and example process improvements were tested. 


\subsubsection{Tradeoff Between CAPX and $O P X$}

Cost tradeoff assessments from the generic TEA model established an approximate correlation between the breakeven revenue required to achieve a NPV of $\$ 0$ as a function of capital and operating costs:

$$
\text { Breakeven Revenue }\left(\frac{\$}{\mathrm{yr}}\right) \approx 0.140 * \operatorname{CAPX}(\$)+(1+1.44 \%) * \mathrm{OPX}\left(\frac{\$}{\mathrm{yr}}\right)
$$

This expression approximates the total revenue for the process from all sources, including fuels, co-products, and credits, under $\mathrm{n}^{\text {th }}$ plant TEA assumptions. There is a slight premium on OPX due to decreased production during plant start-up in the first year, with the assumptions about start-up time, production during startup, and fixed versus operating costs having a slight impact on this value. The CAPX coefficient depends on assumptions related to the cost of capital and its weight on the overall fuel cost. Under the $\mathrm{n}^{\text {th }}$ plant assumptions, this expression gives a tradeoff of $\$ 7.3$ CAPX as equivalent to \$1 $\mathrm{yr}^{-1} \mathrm{OPX}$ - i.e., the revenue requirement (and minimum fuel selling price) remain constant for a decrease in CAPX of $\$ 7.3$ with an increase in OPX of $\$ 1 \mathrm{yr}^{-1}$. This tradeoff is important for algal systems design: every $\$ 7.3$ increase in capital costs must be matched by at least $\$ 1 \mathrm{yr}^{-1}$ in operational savings to avoid impacting fuel price. The reciprocal is also true, in that capital costs can be decreased by this amount in exchange for higher operating costs.

This tradeoff ratio was examined across the range of TEA assumptions, and found to be most sensitive to those inputs that affect the impact of capital costs, especially IRR. This trend again demonstrates the interrelation of time, IRR-based discounting, and the cost of capital in this type of TEA analysis. At $10 \%$ IRR, for instance, $50 \%$ of the net present value of revenue is captured before year 8 , and $75 \%$ is captured by year 13 . Higher IRR values give even greater weight to early or upfront costs, especially CAPX, increasing their impact on overall results. As such, there is also greater benefit per dollar reduction: at $15 \%$ IRR the tradeoff ratio shrinks to $\$ 5.4$ CAPX per $\$ 1 \mathrm{yr}^{-1}$ OPX, Figure 5 . Alternatively, a lower IRR decreases the impact of earlier costs, requiring larger CAPX reductions per equivalent OPX. This change is approximately linear between $8 \%$ and $15 \%$ IRR $\left(r^{2}=0.98\right)$, with the 
tradeoff value growing to $\$ 8.4$ CAPX per $\$ 1 \mathrm{yr}^{-1} \mathrm{OPX}$ at $8 \%$ IRR and to $\$ 10.9$ at $5 \%$ IRR. Other TEA assumptions that impact the weight of CAPX affect the tradeoff value for similar reasons. A lower 5\% loan rate decreases the cost of capital and raises the tradeoff value to $\$ 8$ CAPX per $\$ 1 \mathrm{yr}^{-1} \mathrm{OPX}$ at the baseline IRR of $10 \%$. Longer depreciation schemes slow the write-off of upfront costs and increase taxes, with a 30-year linear scheme shrinking the tradeoff to $\$ 6.2$ CAPX. These trends suggest that decreasing capital costs for algal systems also decreases TEA result sensitivity to assumptions.

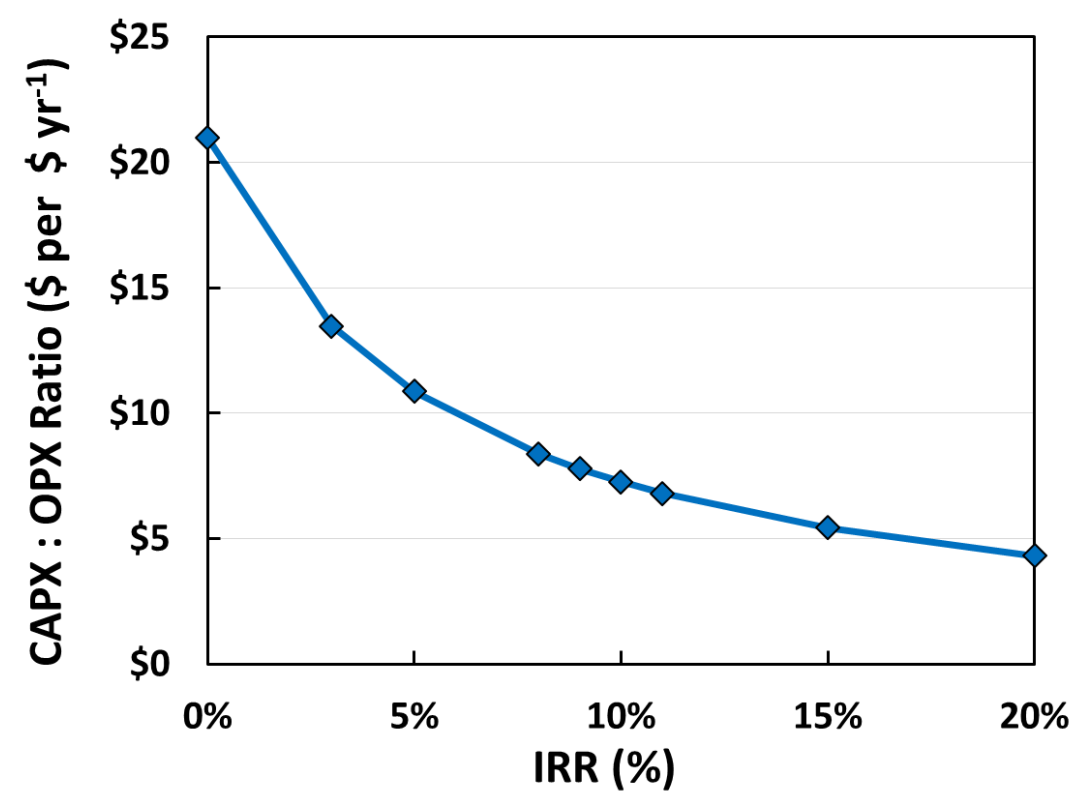

Figure 5: The change in the CAPX: OPX tradeoff ratio with IRR. 10\% IRR is the baseline for $n^{\text {th }}$ plant assumptions. Higher IRR puts greater weight on upfront CAPX costs, increasing the benefit of CAPX reductions Lower IRR decreases the impact of earlier costs, requiring larger CAPX reductions per equivalent $O P X$.

The interrelation of IRR, time, and weight of capital costs has real-world implications beyond sensitivity studies on $\mathrm{n}^{\text {th }}$ plant assumptions. In this type of TEA analysis, IRR is usually set equal to the weighted average cost of capital (WACC), a relationship between the cost of equity (stocks), the cost of debt (loan rate), and the percentage of each type of the total financing. As discussed in Bole et al. (2010), not only is equity always more expensive, but the equity rate also includes a premium for perceived project risk. The $\mathrm{n}^{\text {th }}$ plant assumption is representative of an average for established technologies like corn ethanol, with WACC / IRR in the $7-13 \%$ range. For emerging technologies such as cellulosic or algal fuels, without federal loan support the IRR could easily be $15 \%, 20 \%$, or more. This uncertainty in IRR 
affects only the CAPX contribution to the fuel price results, but the impact can be significant. A $7-13 \%$ IRR range for the baseline HTL in this study leads to fuel price range of $\$ 4.71-\$ 6.05 \mathrm{gge}^{-1}$, while $20 \%$ IRR results in $\$ 7.73 \mathrm{gge}^{-1}$. At $20 \%$ IRR, the tradeoff ratio also shrinks to $\$ 4.3$ CAPX per $\$ 1 \mathrm{yr}^{-1} \mathrm{OPX}$. Given the increased benefit of capital cost reductions at higher IRR, this trend suggests even greater importance in doing so for higher risk projects, even at the cost of moderate increases in OPX. Together, these results further demonstrate the need to reduce capital costs for algal systems, both for modeling and for real-world implementation.

\subsubsection{Comparison to Corn Ethanol}

The relationship between CAPX, OPX, and process revenue allows for the comparison of algal fuel pathways to corn and cellulosic ethanol. The breakeven revenue approximation was normalized by

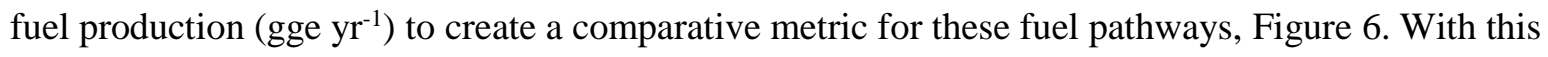
metric, the previously established tradeoff of $\$ 7.3$ CAPX to $\$ 1 \mathrm{yr}^{-1}$ OPX creates lines of constant $\$$ gge $^{-1}$ fuel cost in Figure 6 (the black, red, and blue lines). In the figure, OPX costs dominate processes in the upper left quadrant, while CAPX dominates those in the lower right. Economical processes are those towards the lower left quadrant, namely at or below the black $\$ 3 g^{-1} e^{-1}$ line. The first-of-a-kind algal pathway is not shown in the figure due to high costs (with CAPX of $\$ 46.5 \mathrm{gge}^{-1} \mathrm{yr}^{-1}$ CAPX and OPX of $\$ 5.2 \mathrm{gge}^{-1}$ ). The baseline HTL, protein extraction, and fractionation pathways are shown by the large green, orange, and red squares, respectively. Total OPX costs (before co-product credits) for the protein extraction and fractionation pathways are shown by the smaller orange and red squares. 


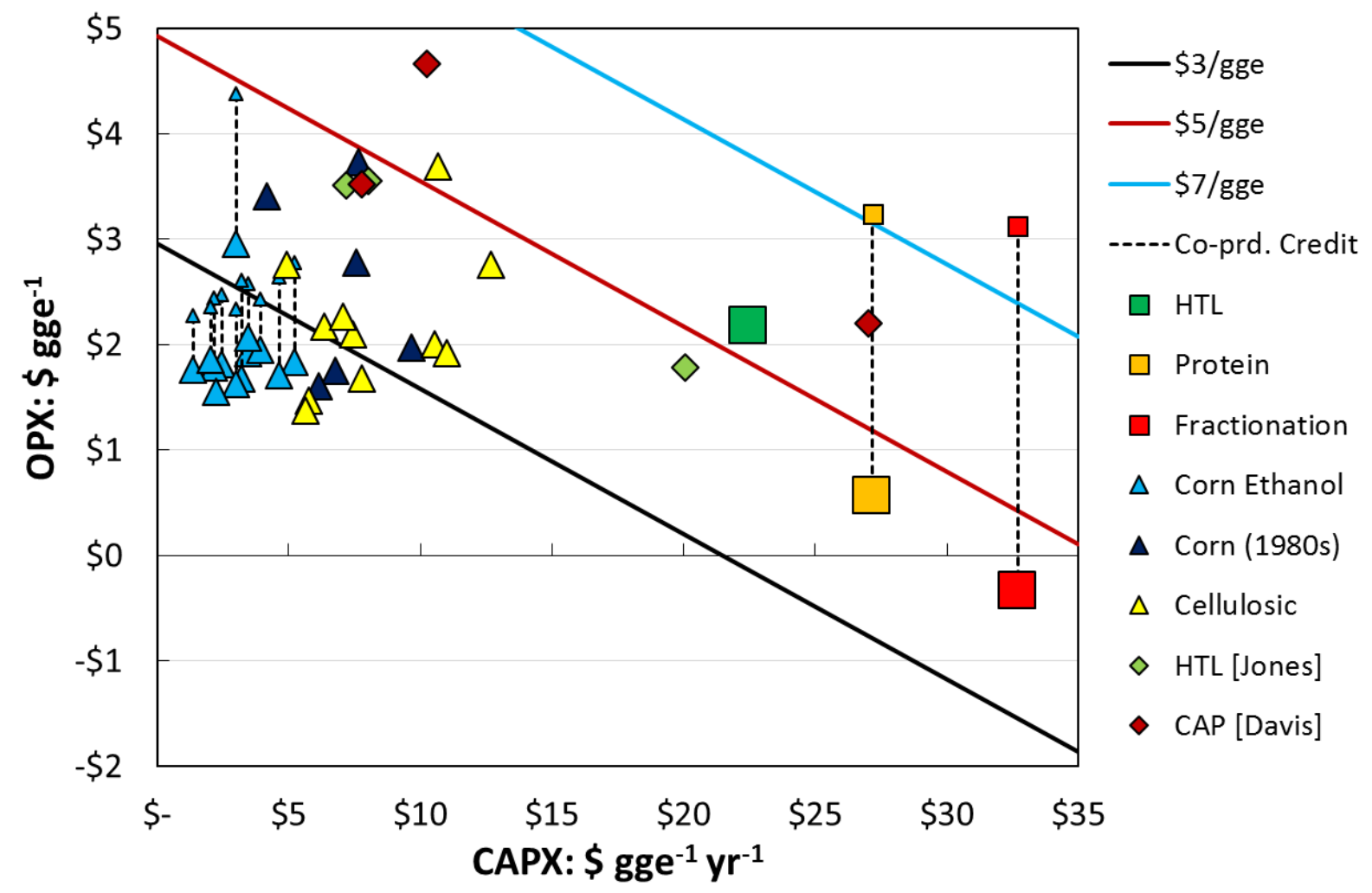

Figure 6: Comparison of algal fuel pathways to corn and cellulosic ethanol, by normalized capital (\$ gge $\left.{ }^{1} y r^{-1}\right)$ and operational $\left(\$ g g e^{-1}\right)$ costs. Diagonal lines represent lines of constant fuel cost $(\$ 3$, $\$ 5$, and $\$ 7$ $\left.g e^{-1}\right)$. The three algal biofuel pathways developed for this study are shown by colored squares: green for baseline HTL, orange for protein extraction, and red for fractionation. The total OPX (before co-product credits) for the protein extraction, fractionation, and corn ethanol pathways is shown by the small points for each. Subtracting co-product credits from this total (dashed lines) yields overall net OPX for each study, shown by the larger points.

Results for corn ethanol are also presented with large light-blue triangles, connected to the smaller triangles representing total production costs before co-product credits (dashed lines). As seen, corn ethanol costs are dominated by OPX, particularly corn prices. Variability in corn prices contributes to the reported range of total OPX. However, the value of co-products also tracks with changing commodity prices, and when subtracted from the total gives a more tightly clustered net OPX, generally around $\$ 2 \mathrm{gge}^{-1}$ or lower. CAPX costs are similarly clustered, mostly between $\$ 2-\$ 5 \mathrm{gge}^{-1} \mathrm{yr}^{-1}$. The narrow range of both CAPX and net OPX costs is as expected for an established technology with already existing large scale production plants currently in operation, with production of $25-100$ million gals $\mathrm{yr}^{-1}$ (Irwin, 2018; Shapouri and Gallagher, 2005; Solomon et al., 2007; Whims, 2002). In contrast, corn ethanol production in the 1980s (as the technology was developing) shows a much greater range of net 
OPX costs, $\$ 1.6-\$ 3.7 \mathrm{gge}^{-1}$, along with higher CAPX, of $\$ 4-\$ 10 \mathrm{gge}^{-1} \mathrm{yr}^{-1}$ (dark blue triangles). As a developing technology, cellulosic ethanol shows a similarly large range in both OPX and CAPX compared with 1980s corn ethanol, with net OPX of $\$ 1.4-\$ 3.7 \mathrm{gge}^{-1}$ and CAPX of $\$ 5-\$ 13 \mathrm{gge}^{-1} \mathrm{yr}^{-1}$. Feedstock and other operating costs drive the OPX range seen for cellulosic systems. At least one cellulosic plant in current operation approaches a $\$ 3 \mathrm{gge}^{-1}$ fuel price, through a combination of relatively lower CAPX and feedstock costs (Yu et al., 2016). It is expected that as the technology develops the CAPX and OPX ranges seen will decrease and approach that of corn ethanol.

The algal fuel pathways modeled here are driven primarily by CAPX costs, which are 7 to 10 times higher than those for corn ethanol. The baseline HTL has the highest fuel production, leading to the lowest relative CAPX, at $\$ 23 \mathrm{gge}^{-1} \mathrm{yr}^{-1}$. For the protein extraction and fractionation pathways, the diversion of biomass to co-products decreases fuel production and thus increases relative CAPX to \$27 and $\$ 33 \mathrm{gge}^{-1} \mathrm{yr}^{-1}$, respectively. Total OPX costs for these two pathways (small squares) are generally higher than that for corn and cellulosic ethanol, though the large co-product credits (dashed lines) for these algal pathways are sufficient to result in significantly lower net OPX (large squares). As seen, coproduct prices leading to a negative net OPX for algal fuel pathways are required for processes with CAPX above $\$ 21.5 \mathrm{gge}^{-1} \mathrm{yr}^{-1}$ to reach $\$ 3 \mathrm{gge}^{-1}$. The baseline HTL pathway has lower total OPX costs that are comparable to ethanol, but because it produces no significant co-products there are limited opportunities for further net OPX decreases.

These results can be compared against previous HTL and CAP studies. The points on the left side of Figure 6 represent downstream-only models that purchase algal biomass at a fixed price (Davis et al., 2014; Jones et al., 2014; Schwab, 2016), while those on the right replace the purchased biomass with the ORP model from (Davis et al., 2016). As expected, the ORP-model results are comparable to the algal pathways in this study, particularly the baseline HTL. For these high CAPX processes, both cost reduction and co-product credits leading to a negative net OPX are necessary to reach $\$ 3 \mathrm{gge}^{-1}$. The downstream-only models provide a useful comparison with corn and cellulosic ethanol, as these plants also purchase biomass feedstocks at a fixed price per ton. The high cost of algal feedstock is the largest 
driver of net OPX in these studies, contributing $\$ 3-\$ 4.2$ gge $^{-1}$ when algal biomass is $\$ 430-\$ 494$ ton $^{-1}$. Feedstock costs for competitive ethanol processes are much lower, $\$ 90-\$ 200$ ton $^{-1}$ for corn and as low as $\$ 35$ ton $^{-1}$ for cellulosic feedstocks. The CAPX for algal conversion technologies is also higher, 2 to 3 times that for corn ethanol, though comparable to the average for cellulosic processes. For downstreamonly models, the cost of algal biomass would need to decrease by half, to $\$ 230$ per ton, for the processes to approach a $\$ 3 \mathrm{gge}^{-1}$ fuel price. Without co-product credits, this required level of cost reductions may prove challenging to implement.

\subsubsection{Potential Improvements}

The comparison with corn ethanol presents areas for improving the viability of algal pathways. One consideration is to reduce CAPX. For corn ethanol, relative CAPX has decreased by half since the 1980s, through a combination of increased process yields, streamlined production pathways, improved technologies, and larger plant scales (Hettinga et al., 2009). Because algal processes are dominated by much higher CAPX, a decrease by half for these scenarios would require reductions of $\$ 11-\$ 16 \mathrm{gge}^{-1} \mathrm{yr}^{-}$ ${ }^{1}$, significantly greater than the $\$ 2-\$ 5 \mathrm{gge}^{-1} \mathrm{yr}^{-1}$ seen for corn ethanol. Several avenues for reductions were examined here, including increased productivity, process improvements, and higher fuel yields.

Productivity increases are a widely considered option for fuel price decreases through reduction of relative CAPX. The cost changes from a doubling of growth rate from 25 to $50 \mathrm{~g} \mathrm{~m}^{-2} \mathrm{day}^{-1}$ for the algal pathways in this study were examined. This doubling of productivity did not halve the relative CAPX, instead only decreasing it by $32-38 \%$, or $\$ 7.3-\$ 12.3 \mathrm{gge}^{-1} \mathrm{yr}^{-1}$ for the pathways modeled. While the impact from the growth system is halved, the effect is offset by downstream equipment that scales up with increased flowrates from higher volumes of biomass production. Given that the processes are already modeled at industrial scales (10,000 acres, or $35-50$ million gge $\mathrm{yr}^{-1}$ at the baseline productivity), benefits from upscaling this downstream equipment are much more limited than for smaller facilities. Furthermore, productivities higher than 25 or $30 \mathrm{~g} \mathrm{~m}^{-2}$ day $^{-1}$ may require more capital intensive growth systems such as photobioreactors (PBRs), which increase costs dramatically: Davis et al. (2011) and Richardson et al. (2012) estimate PBR CAPX equivalent to more than $\$ 100 \mathrm{gge}^{-1} \mathrm{yr}^{-1}$ at $25 \mathrm{~g} \mathrm{~m}^{-2} \mathrm{day}^{-1}$. 
Increasing productivity from currently demonstrated (lower) values up to $25 \mathrm{~g} \mathrm{~m}^{-2} \mathrm{day}^{-1}$, however, is critically important. Halving the productivity of the algal pathways in this study to $12.5 \mathrm{~g} \mathrm{~m}^{-2} \mathrm{day}^{-1}$ led to relative CAPX increases of $\$ 13.2$ - $\$ 23.5 \mathrm{gge}^{-1} \mathrm{yr}^{-1}$. This increase is the result of both a doubling of the impact from the growth system and downscaling effects from the conversion system. The baseline HTL pathway saw the lowest relative CAPX change with productivity, while the fractionation model saw the largest change, suggesting that high relative CAPX processes are more sensitive to growth rate assumptions. A reasonable increase in productivity from 25 to $30 \mathrm{~g} \mathrm{~m}^{-2} \mathrm{day}^{-1}$ provided small improvements for these pathways, decreasing relative CAPX by $\$ 2.3-\$ 4 \mathrm{gge}^{-1} \mathrm{yr}^{-1}$. Fixed OPX costs also decreased slightly, by $\$ 0.1-\$ 0.16$ gge $^{-1}$, from a combination of relatively lower maintenance costs (which scale with CAPX) and labor (which remained constant). These small productivity improvements can thus provide moderate benefits to process economics, though growth rate increases alone are unlikely to lead to $\$ 3 \mathrm{gge}^{-1}$ fuel costs.

Other process improvements were also examined. Some HTL work is exploring the removal of the $\mathrm{CHG}$ for nutrient recovery, and instead recycling the aqueous phase directly back to the growth system (Selvaratnam et al., 2015). Doing so can decrease the CAPX of the models in the this study by $\$ 2.2-\$ 3.4$ gge $^{-1}$ year $^{-1}$, though this benefit decreases to $\$ 1.4-\$ 3.3$ gge $^{-1}$ year $^{-1}$ when productivity is increased to $30 \mathrm{~g} \mathrm{~m}^{-2} \mathrm{day}^{-1}$. Another possibility is the increase of conversion efficiency, i.e., fuel production per ton of algae. However, the HTL biocrude yields modeled here are already fairly optimistic. Though yield increases up to the 59\% reported by Jones et al. (2014) may be feasible, improvements beyond this point could be limited. Decreasing the cost of downstream conversion technologies is also limited in overall benefits, as upstream costs represent two thirds of the relative CAPX for the models in this study, $\$ 14-\$ 21$ gge $^{-1}$ year $^{-1}$. While some combination of these improvements can be beneficial, large reductions in relative CAPX costs are likely unrealistic, and algal biofuels will continue to be a technology dominated by high capital requirements, especially for HTL-based conversion pathways. Given these limits for large CAPX reductions, a greater emphasis on OPX is required. Some opportunities for decreases to total OPX may exist, such as onsite recycle of $\mathrm{CO}_{2}$ from downstream 
conversion (100\% purchase of $\mathrm{CO}_{2}$ contributes $\$ 0.7-\$ 1.0 \mathrm{gge}^{-1}$ ) or decreased energy usage, especially for co-product pathways (currently $\$ 0.7 \mathrm{gge}^{1}$ for both protein extraction and fractionation). However, by comparing to corn ethanol (Figure 6), it appears unlikely that total OPX for algal processes can decrease significantly below $\$ 2 \mathrm{gge}^{-1}$. Energy and other non-feedstock operating costs for corn ethanol have been optimized as the technology became established, representing about $\$ 1 \mathrm{gge}^{-1}$ of the fuel cost, and similar costs for algae are unlikely to be lower. Feedstock costs for algae $\left(\mathrm{CO}_{2}\right.$ and nutrients) currently contribute $\$ 1 \mathrm{gge}^{-1}$ or more, while fixed OPX costs scale with CAPX and are comparatively high (Figure 2). As such, co-products and other credits are crucial for large reductions in net OPX, which must be increasingly negative for higher CAPX systems (above $\$ 21.5 \mathrm{gge}^{-1} \mathrm{year}^{-1}$, or to moving toward the right of the figure).

To demonstrate the combination of improvements required for algal fuels to reach the $\$ 3 \mathrm{gge}^{-1}$, optimization scenarios were integrated into the baseline HTL, protein extraction, and fractionation models. These improvements included: increased productivity from 25 to $30 \mathrm{~g} \mathrm{~m}^{-2} \mathrm{~d}^{-1}$; the removal of the CHG; recycling $50 \%$ of the process $\mathrm{CO}_{2}$ to decrease OPX; baseline co-product prices with additional credits from selling biochar and struvite at $\$ 100$ and $\$ 500$ ton $^{-1}$, respectively; and the inclusion of carbon tax from the 3\% SCC model $\left(\$ 52-\$ 85\right.$ tonne $\left.^{-1}\right)$. Together, increased productivity and the removal of the CHG decreased CAPX for all three models by $\$ 5.5 \mathrm{gge}^{-1} \mathrm{yr}^{-1}$ each (a $17-25 \%$ reduction). The combination of $\mathrm{CO}_{2}$ recycling, credits for biochar and struvite, and the carbon capture credits decreased net OPX by $\$ 0.75, \$ 0.88$, and $\$ 1.14 \mathrm{gge}^{-1}$ for the baseline HTL, protein extraction, and fractionation models, respectively. These improvements were sufficient to lower the fuel cost for protein extraction to $\$ 2.77 \mathrm{gge}^{-1}$ and for fractionation to $\$ 2.37 \mathrm{gge}^{-1}$, Figure 7. Optimization was insufficient for HTL to reach the target, decreasing in price only to $\$ 3.84 \mathrm{gge}^{-1}$. These results show that similar combinations of process improvements can lead algal biofuels to the $\$ 3 \mathrm{gge}^{-1}$ target, but only if processes utilize higher value coproducts to offset costs. 


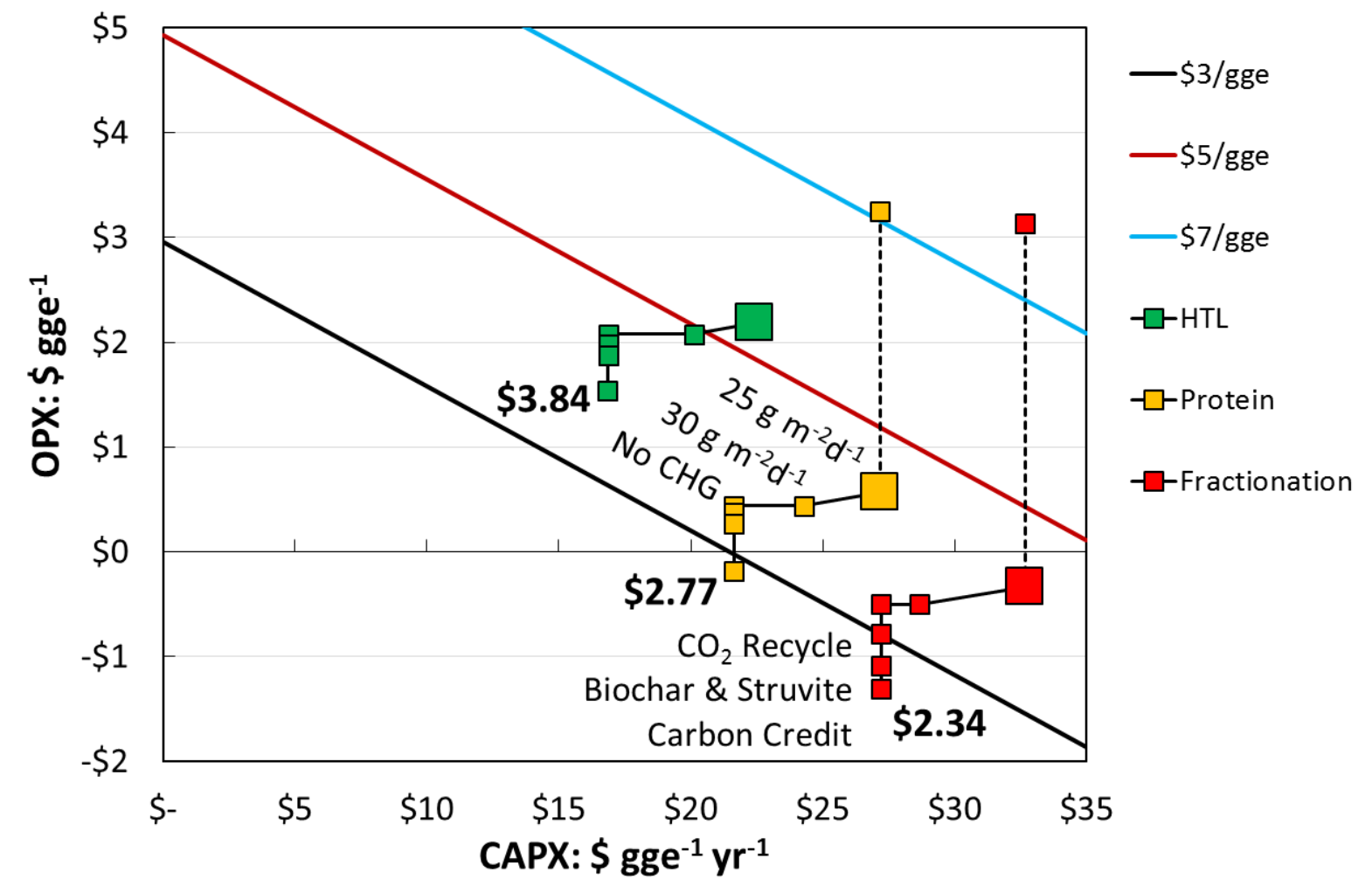

Figure 7: Optimization improvements for the algal biofuel pathways in this study to reach $\$ 3$ gge ${ }^{-1}$. Optimization scenarios included: productivity increase from 25 to $30 \mathrm{~g} \mathrm{~m}^{-2} \mathrm{day}^{-1}$; removal of CAPX from the CHG in the HTL system; recycling of 50\% of the HTL process $\mathrm{CO}_{2}$ generated to algal growth to decrease OPX; additional co-product credits from biochar $\left(\$ 100\right.$ ton $\left.^{-1}\right)$ and struvite $\left(\$ 500\right.$ ton $\left.^{-1}\right)$; and carbon credits from the 3\% SCC scenario. The protein extraction and fractionation pathways reach $\$ 2.77$ and $\$ 2.37$ gge $^{-1}$, respectively. Without co-product credits, however, the baseline HTL fails to reach the fuel cost target. 


\section{Conclusions}

A techno-economic analysis of multiple algal biofuel pathways was performed. Baseline results of $\$ 5.37, \$ 4.44, \$ 4.31$, and $\$ 11.13 \mathrm{gge}^{-1}$ were found for HTL, protein extraction, fractionation, and firstof-a-kind pathways. Alternative real-world operation modeling scenarios were considered. Results were found to be sensitive to co-product prices and longer depreciation schemes while benefiting from shortterm subsidies and carbon pricing scenarios. Tradeoffs between capital and operating costs were examined and used to compare algal fuels to corn and cellulosic ethanol. Improvements to the viability of

algal fuel processes were observed and tested, demonstrating the necessity of high value co-products and moderate cost decreases. 


\section{References}

Alibaba Group, 2018. Alibaba.com [WWW Document]. URL www.alibaba.com. Accessed March 2018. Amanor-Boadu, V., Pfromm, P.H., Nelson, R., 2014. Economic feasibility of algal biodiesel under alternative public policies. Renew. Energy 67, 136-142.

Argonne National Laboratory, 2017. Greenhouse gases, regulated emissions, and energy use in transportation (GREET) model. https://greet.es.anl.gov/

Barlow, J., Sims, R.C., Quinn, J.C., 2016. Techno-economic and life-cycle assessment of an attached growth algal biorefinery. Bioresour. Technol. 220, 360-368.

Batan, L.Y., Graff, G.D., Bradley, T.H., 2016. Techno-economic and Monte Carlo probabilistic analysis of microalgae biofuel production system. Bioresour. Technol. 219, 45-52.

Beal, C.M., Davidson, F.T., Webber, M.E., Quinn, J.C., 2016. Flare gas recovery for algal protein production. Algal Res. 20, 142-152.

Beal, C.M., Gerber, L.N., Sills, D.L., Huntley, M.E., Machesky, S.C., Walsh, M.J., Tester, J.W., Archibald, I., Granados, J., Greene, C.H., 2015. Algal biofuel production for fuels and feed in a 100-ha facility: A comprehensive techno-economic analysis and life cycle assessment. Algal Res. 10, 266-279.

Bole, T., Londo, M., van Stralen, J., Uslu, A., 2010. Overcoming the initial investment hurdle for advanced biofuels: an analysis of biofuel-related risks and their impact on project financing (No. D7.1), ELOBIO subtask 7. Energy Research Centre of the Netherlands.

Carriquiry, M.A., Du, X., Timilsina, G.R., 2011. Second generation biofuels: Economics and policies. Energy Policy 39, 4222-4234.

Chew, K.W., Yap, J.Y., Show, P.L., Suan, N.H., Juan, J.C., Ling, T.C., Lee, D.-J., Chang, J.-S., 2017. Microalgae biorefinery: High value products perspectives. Bioresour. Technol. 229, 53-62.

Connelly, E.B., Colosi, L.M., Clarens, A.F., Lambert, J.H., 2015. Life Cycle Assessment of Biofuels from Algae Hydrothermal Liquefaction: The Upstream and Downstream Factors Affecting Regulatory Compliance. Energy Fuels 29, 1653-1661.

Davis, R., Aden, A., Pienkos, P.T., 2011. Techno-economic analysis of autotrophic microalgae for fuel production. Appl. Energy 88, 3524-3531.

Davis, R., Kinchin, C., Markham, J., Tan, E., Laurens, L., Sexton, D., Knorr, D., Schoen, P., Lukas, J., 2014. Process design and economics for the conversion of algal biomass to biofuels: algal biomass fractionation to lipid-and carbohydrate-derived fuel products. National Renewable Energy Laboratory (NREL), Golden, CO.

Davis, R., Markham, J., Kinchin, C., Grundl, N., Tan, E.C., Humbird, D., 2016. Process Design and Economics for the Production of Algal Biomass: Algal Biomass Production in Open Pond.

DeRose, K., DeMill, C., Davis, R.W., Quinn, J.C., 2018. Integrated Techno Economic and Life Cycle Assessment of the Conversion of High Productivity, Low Lipid Algae to Renewable Fuels.

Federal Financing Bank, 2018. Monthly Activity Reports [WWW Document]. URL https://ffb.treasury.gov/reports/monthly-activity-reports/. Accessed March 2018. 
Frank, E., Pegallapati, A.K., Davis, R., Markham, J., Coleman, A., Jones, S., Wigmosta, M.S., Zhu, Y., 2016. Life-cycle analysis of energy use, greenhouse gas emissions, and water consumption in the 2016 MYPP algal biofuel scenarios. Argonne National Laboratory (ANL).

Frank, E., Wang, M., Han, J., Elgowainy, A., Palou-Rivera, I., 2011. Life Cycle Analysis of Algae-Based Fuels with the GREET Model. Energy Syst. Div. Argonne Lab. San Franc. USA.

Gnansounou, E., Kenthorai Raman, J., 2016. Life cycle assessment of algae biodiesel and its co-products. Appl. Energy 161, 300-308.

Hettinga, W.G., Junginger, H.M., Dekker, S.C., Hoogwijk, M., McAloon, A.J., Hicks, K.B., 2009. Understanding the reductions in US corn ethanol production costs: An experience curve approach. Energy Policy 37, 190-203.

Hise, A.M., Characklis, G.W., Kern, J., Gerlach, R., Viamajala, S., Gardner, R.D., Vadlamani, A., 2016. Evaluating the relative impacts of operational and financial factors on the competitiveness of an algal biofuel production facility. Bioresour. Technol. 220, 271-281.

Humbird, D., Davis, R., Tao, L., Kinchin, C., Hsu, D., Aden, A., Schoen, P., Lukas, J., Olthof, B., Worley, M., 2011. Process design and economics for biochemical conversion of lignocellulosic biomass to ethanol: dilute-acid pretreatment and enzymatic hydrolysis of corn stover. National Renewable Energy Laboratory (NREL), Golden, CO.

Interagency Working Group on Social Cost of Carbon, 2016. Technical Support Document: Technical Update of the Social Cost of Carbon for Regulatory Impact Analysis-Under Executive Order 12866.

Irwin, S., 2018. What happened to the profitability of Ethanol Production in 2017? Dep. Agric. Consum. Econ. Univ. Ill. Urbana-Champaign, Farmdoc Daily (8):45.

http://farmdocdaily.illinois.edu/2018/03/profitability-of-ethanol-production-in-2017.html

Jones, S., Zhu, Y., Anderson, D., Hallen, R., Elliott, D.C., Schmidt, A.J., Albrecht, K., Hart, T., Butcher, M., Drennan, C., others, 2014. Process design and economics for the conversion of algal biomass to hydrocarbons: whole algae hydrothermal liquefaction and upgrading. US Dep. Energy Bioenergy Technol. Off.

Kane, S.M., Reilly, J.M., 1989. Economics of Ethanol Production in the United States (AER No. 607). U.S. Dept. of Agriculture, Economic Research Service.

Kern, J.D., Hise, A.M., Characklis, G.W., Gerlach, R., Viamajala, S., Gardner, R.D., 2017. Using life cycle assessment and techno-economic analysis in a real options framework to inform the design of algal biofuel production facilities. Bioresour. Technol. 225, 418-428.

Li, Y., Leow, S., Fedders, A.C., Sharma, B.K., Guest, J.S., Strathmann, T.J., 2017. Quantitative multiphase model for hydrothermal liquefaction of algal biomass. Green Chem 19, 1163-1174.

Mata, T.M., Martins, A.A., Caetano, N.S., 2010. Microalgae for biodiesel production and other applications: A review. Renew. Sustain. Energy Rev. 14, 217-232.

McAloon, A., Taylor, F., Yee, W., Ibsen, K., Wooley, R., 2000. Determining the cost of producing ethanol from corn starch and lignocellulosic feedstocks. Natl. Renew. Energy Lab. Rep.

Mu, D., Ruan, R., Addy, M., Mack, S., Chen, P., Zhou, Y., 2017. Life cycle assessment and nutrient analysis of various processing pathways in algal biofuel production. Bioresour. Technol. 230, 33-42. 
Quinn, J.C., Davis, R., 2015. The potentials and challenges of algae based biofuels: A review of the techno-economic, life cycle, and resource assessment modeling. Bioresour. Technol. 184, 444-452.

Quinn, J.C., Smith, T.G., Downes, C.M., Quinn, C., 2014. Microalgae to biofuels lifecycle assessment Multiple pathway evaluation. Algal Res. 4, 116-122.

Richardson, J.W., Johnson, M.D., Outlaw, J.L., 2012. Economic comparison of open pond raceways to photo bio-reactors for profitable production of algae for transportation fuels in the Southwest. Algal Res. $1,93-100$.

Schenk, P.M., Thomas-Hall, S.R., Stephens, E., Marx, U.C., Mussgnug, J.H., Posten, C., Kruse, O., Hankamer, B., 2008. Second Generation Biofuels: High-Efficiency Microalgae for Biodiesel Production. BioEnergy Res. 1, 20-43.

Schwab, A., 2016. Bioenergy Technologies Office Multi-Year Program Plan. March 2016. Bioenergy Technologies Office, Washington, DC (United States).

Selvaratnam, T., Reddy, H., Muppaneni, T., Holguin, F.O., Nirmalakhandan, N., Lammers, P.J., Deng, S., 2015. Optimizing energy yields from nutrient recycling using sequential hydrothermal liquefaction with Galdieria sulphuraria. Algal Res. 12, 74-79.

Shapouri, H., Gallagher, P., 2005. USDA's 2002 Ethanol Cost-of-Production Survey (No. 841), Agricultural Economic Report. U.S. Dept. of Agriculture, Office of the Chief Economist, Office of Energy Policy and New Uses.

Shewmaker, G., Hall, J., Baker, S., 2013. Getting the most feed nutrient for the dollar. University of Idaho Extension.

Solomon, B.D., Barnes, J.R., Halvorsen, K.E., 2007. Grain and cellulosic ethanol: History, economics, and energy policy. Biomass Bioenergy 31, 416-425.

Summers, H.M., Ledbetter, R.N., McCurdy, A.T., Morgan, M.R., Seefeldt, L.C., Jena, U., Kent Hoekman, S., Quinn, J.C., 2015. Techno-economic feasibility and life cycle assessment of dairy effluent to renewable diesel via hydrothermal liquefaction. Bioresour. Technol. 196, 431-440.

Tyner, W.E., 2015. US ethanol policy-Possibilities for the future. Dept Agric. Econ. Purdue Univ. Ext. BioEnergy ID-342-W.

U.S. DOE Alternative Fuels Data Center, 2018. Expired, Repealed, and Archived Incentrives and Laws [WWW Document]. URL https://www.afdc.energy.gov/laws/laws_expired?jurisdiction=US

Vanthoor-Koopmans, M., Wijffels, R.H., Barbosa, M.J., Eppink, M.H.M., 2013. Biorefinery of microalgae for food and fuel. Bioresour. Technol. 135, 142-149.

Walsh, M.J., Gerber Van Doren, L., Sills, D.L., Archibald, I., Beal, C.M., Lei, X.G., Huntley, M.E., Johnson, Z., Greene, C.H., 2016. Algal food and fuel coproduction can mitigate greenhouse gas emissions while improving land and water-use efficiency. Environ. Res. Lett. 11, 114006.

Whims, J., 2002. Corn Based Ethanol Costs and Margins Attachment 1. Agric. Mark. Resour. Cent. Dep. Agric. Econ. Kans. State Univ. Manhattan Kans. USA. 
Williams, P.R.D., Inman, D., Aden, A., Heath, G.A., 2009. Environmental and Sustainability Factors Associated With Next-Generation Biofuels in the U.S.: What Do We Really Know? Environ. Sci.

Technol. 43, 4763-4775.

Yacobucci, B.D., 2008. Biofuels Incentives: A Summary of Federal Programs. Congressional Research Service: Resources, Science, and Industry Division.

Yu, Y.-S., Giles, B., Oh, V., 2016. Uncovering the cost of cellulosic ethanol production. Lux Res. Boston MA. http://biomassmagazine.com/articles/12958/lux-cellulosic-ethanol-price-hinges-on-feedstock-cost

Zhao, L., Zhang, X., Xu, J., Ou, X., Chang, S., Wu, M., 2015. Techno-Economic Analysis of Bioethanol Production from Lignocellulosic Biomass in China: Dilute-Acid Pretreatment and Enzymatic Hydrolysis of Corn Stover. Energies 8, 4096-4117. 


\section{APPENDIX}

Engineering Process Model \& TEA Cost Assumptions

Table A1: Engineering process model parameters and associated variable operating costs

\begin{tabular}{|c|c|c|c|c|c|}
\hline & $\begin{array}{l}\text { Baseline } \\
\text { HTL }\end{array}$ & $\begin{array}{l}\text { Protein } \\
\text { Extraction }\end{array}$ & Fractionation & $\begin{array}{l}\text { First-of-a- } \\
\text { Kind }\end{array}$ & Units / Notes \\
\hline Cultivation Area & 10,000 & 10,000 & 10,000 & 247 & Acres \\
\hline Facility Size & 12,615 & 12,615 & 12,615 & 376 & Acres \\
\hline Productivity & 25 & 25 & 25 & 20 & $\begin{array}{l}\text { g AFDW m- } \\
{ }^{2} \text { day }^{-1}\end{array}$ \\
\hline Ash Content of Algae & $14.2 \%$ & $14.2 \%$ & $2.4 \%$ & $14.2 \%$ & $\%$ dry weight \\
\hline Protein & $31.3 \%$ & $31.3 \%$ & $13.2 \%$ & $31.3 \%$ & $\%$ dry weight \\
\hline Carbohydrates & $19.1 \%$ & $19.1 \%$ & $52.8 \%$ & $19.1 \%$ & $\%$ dry weight \\
\hline Lipids & $20.8 \%$ & $20.8 \%$ & $27.4 \%$ & $20.8 \%$ & $\%$ dry weight \\
\hline Algae TPD & 1300 & 1300 & 1165 & 25.6 & dry tons day ${ }^{-1}$ \\
\hline $\mathrm{NH}_{3}$ Required (after recycle) & 13.4 & 53.0 & 5.3 & - & $\mathrm{kg} /$ ton algae \\
\hline DAP (or $3 x P h o s)$ Required & 28.6 & 28.6 & 10.4 & 23.7 & $\mathrm{~kg} /$ ton algae \\
\hline $\mathrm{CO}_{2}$ Required & 1,895 & 1,895 & 1,947 & 1,895 & $\mathrm{~kg} /$ ton algae \\
\hline Biomass to HTL & 49,157 & 35,309 & 18,833 & 1,182 & kg biomass / hr \\
\hline Biocrude Yield & $50 \%$ & $60 \%$ & $70 \%$ & $\begin{array}{l}50 \% \text { Algae } \\
10 \% \text { Sludge }\end{array}$ & $\begin{array}{l}\text { Of biomass } \\
\text { AFDW }\end{array}$ \\
\hline Biochar Yield & $10 \%$ & $14 \%$ & $7 \%$ & $\begin{array}{l}10 \% \text { Algae } \\
20 \% \text { Sludge }\end{array}$ & $\begin{array}{l}\text { Of biomass dry } \\
\text { weight }\end{array}$ \\
\hline Total GGE Yield & 118.6 & 95.6 & 88.7 & 124.7 & gge / ton algae \\
\hline Biochar Yield & 90.7 & 90.7 & 27.2 & 130.6 & $\mathrm{~kg} /$ ton algae \\
\hline Electricity - Growth & 1.620 & 1.620 & 1.620 & 1.818 & MJ / kg algae \\
\hline HTL & 0.347 & 0.347 & 0.347 & 0.347 & $\mathrm{MJ} / \mathrm{kg}$ biomass \\
\hline Other Downstream & - & 0.947 & 0.114 & - & $\mathrm{MJ} / \mathrm{kg}$ algae \\
\hline Heat - Annualized Drying & 1.426 & 1.426 & 1.426 & 1.426 & $\mathrm{MJ} / \mathrm{kg}$ algae \\
\hline HTL & 1.694 & 1.694 & 0.662 & 1.694 & $\mathrm{MJ} / \mathrm{kg}$ biomass \\
\hline Other Downstream & - & 1.00 & 4.386 & - & MJ / kg algae \\
\hline Total Electricity & 1,784 & 2,554 & 1,708 & 2,033 & MJ / ton algae \\
\hline Total Heat & 2,830 & 3,304 & 5,529 & 2,864 & MJ / ton algae \\
\hline $\begin{array}{l}\text { Feedstock } \mathrm{CO}_{2} \text { Cost: } \\
\mathrm{M} \$ / \mathrm{yr}\end{array}$ & $\$ 36.6$ & $\$ 36.6$ & $\$ 33.7$ & $\$ 0.72$ & $\begin{array}{l}\$ 45 / \text { metric } \\
\text { tonne }\end{array}$ \\
\hline \multicolumn{6}{|l|}{ Variable OPX: M\$ / yr } \\
\hline Nutrients & $\$ 9.3$ & $\$ 18.6$ & $\$ 4.4$ & $\$ 0.10$ & \\
\hline Natural Gas & $\$ 5.9$ & $\$ 6.9$ & $\$ 10.3$ & $\$ 0.12$ & $\$ 5.1 / 1000 \mathrm{scf}$ \\
\hline Electricity & $\$ 14.7$ & $\$ 21.0$ & $\$ 12.6$ & $\$ 0.33$ & $6.89 \mathbb{C} / \mathrm{kWh}$ \\
\hline Process Chemicals & $\$ 8.5$ & $\$ 14.5$ & $\$ 10 . .2$ & $\$ 0.20$ & \\
\hline Total Var. OPX: M\$ / yr & $\$ 38.3$ & $\$ 60.9$ & $\$ 37.4$ & $\$ 1.47$ & \\
\hline Fuel GGE Conversion & Diesel & Naphtha & Fusel Alcohols & Ethanol & From GREET \\
\hline gal fuel per gge & 1.1 & 1.04 & 0.89 & 0.68 & \\
\hline
\end{tabular}


Table A2: Protein extraction and fractionation sub-process assumptions

\begin{tabular}{|l|l|l|l|}
\hline Protein Extraction & Value & Units & Source \\
\hline Extraction Efficiency & $90 \%$ & & {$[2]$} \\
\hline Homogenization & 0.183 & $\mathrm{kWh} / \mathrm{dry} \mathrm{kg}$ algae & {$[1][3][5]$} \\
\hline Process Heat & 1.00 & $\mathrm{MJ} / \mathrm{dry} \mathrm{kg}$ & {$[1][2][4]$} \\
\hline Process Electricity & 0.08 & $\mathrm{kWh} / \mathrm{dry} \mathrm{kg}$ & {$[1][2][4]$} \\
\hline Methanol & 2.1 & $\mathrm{~g} / \mathrm{kg}$ AFDW & {$[2]$} \\
\hline Ethanol & 39.1 & $\mathrm{~g} / \mathrm{kg}$ AFDW & {$[2]$} \\
\hline Protein Production & $\mathbf{2 5 5 . 6}$ & kg / dry ton algae & \\
\hline & & & \\
\hline Fractionation & High-Value & Fusel Alcohol & Units \\
\hline Process [6] [7] & Fhemical & $97.5 \%$ & $\%$ of carbohydrates / proteins \\
\hline Pretreatment Yield & $90 \%$ & $31.3 \%$ & $\%$ of soluble carbs / proteins \\
\hline Fermentation Usage & $90 \%$ & $39 \%$ & g product / g fermented \\
\hline Product Yield & $\mathbf{2 6 . 9 \%}$ & $98 \%$ & \\
\hline Separation Efficiency & $98 \%$ & $\mathbf{2 8 . 8}$ & kg / dry ton algae \\
\hline Total Production & $\mathbf{1 0 2 . 3}$ & $\mathbf{4 2 . 9}$ & kg / dry ton algae \\
\hline Struvite Production & - & & \\
\hline
\end{tabular}

[1] Frank, E., Wang, M., Han, J., Elgowainy, A., Palou-Rivera, I., 2011. Life Cycle Analysis of AlgaeBased Fuels with the GREET Model. Energy Systems Division, Argonne Laboratory, San Francisco, USA.

[2] Gnansounou, E., Kenthorai Raman, J., 2016. Life cycle assessment of algae biodiesel and its coproducts. Applied Energy 161, 300-308.

[3] Quinn, J.C., Smith, T.G., Downes, C.M., Quinn, C., 2014. Microalgae to biofuels lifecycle assessment - Multiple pathway evaluation. Algal Research 4, 116-122.

[4] Mu, D., Ruan, R., Addy, M., Mack, S., Chen, P., Zhou, Y., 2017. Life cycle assessment and nutrient analysis of various processing pathways in algal biofuel production. Bioresource Technology 230, 33-42.

[5] Vanthoor-Koopmans, M., Wijffels, R.H., Barbosa, M.J., Eppink, M.H.M., 2013. Biorefinery of microalgae for food and fuel. Bioresource Technology 135, 142-149.

[6] Davis, R., Kinchin, C., Markham, J., Tan, E., Laurens, L., Sexton, D., Knorr, D., Schoen, P., Lukas, J., 2014. Process design and economics for the conversion of algal biomass to biofuels: algal biomass fractionation to lipid-and carbohydrate-derived fuel products. National Renewable Energy Laboratory (NREL), Golden, CO.

[7] DeRose, K., DeMill, C., Davis, R.W., Quinn, J.C., 2018. Integrated Techno Economic and Life Cycle Assessment of the Conversion of High Productivity, Low Lipid Algae to Renewable Fuels. 
Table A3: Capital and fixed OPX assumptions for each scenario

\begin{tabular}{|c|c|c|c|c|}
\hline Upstream CAPX (M\$) & \multicolumn{2}{|c|}{$\begin{array}{l}\text { Baseline HTL / Protein } \\
\text { Extraction / Fractionation } \\
(12,615 \text { total acres) }\end{array}$} & \multicolumn{2}{|c|}{$\begin{array}{l}\text { First-of-a-Kind } \\
\text { (376 total acres) }\end{array}$} \\
\hline Installed Costs (TIC) & \multicolumn{2}{|c|}{$\$ 466.2$} & \multicolumn{2}{|l|}{$\$ 12.4$} \\
\hline Cultivation & \multicolumn{2}{|l|}{$\$ 349.2$} & \multicolumn{2}{|l|}{$\$ 8.6$} \\
\hline Harvest & \multicolumn{2}{|l|}{$\$ 79.0$} & \multicolumn{2}{|l|}{$\$ 2.9$} \\
\hline Other $\left(\mathrm{CO}_{2}\right.$, etc $)$ & \multicolumn{2}{|l|}{$\$ 38.0$} & \multicolumn{2}{|l|}{$\$ 0.9$} \\
\hline Other Direct Costs & \multicolumn{2}{|l|}{$\$ 37.4$} & \multicolumn{2}{|l|}{$\$ 1.2$} \\
\hline Cultivation: $1.22 \%$ of IC & \multicolumn{2}{|l|}{$\$ 4.3$} & \multicolumn{2}{|l|}{$\$ 0.1$} \\
\hline Harvest: $17.5 \%$ of IC & \multicolumn{2}{|l|}{$\$ 13.8$} & \multicolumn{2}{|l|}{$\$ 0.5$} \\
\hline Other: $\$ 1,534$ / acre & \multicolumn{2}{|l|}{$\$ 19.4$} & \multicolumn{2}{|l|}{$\$ 0.6$} \\
\hline Indirect Costs & \multicolumn{2}{|l|}{$\$ 174.7$} & \multicolumn{2}{|l|}{$\$ 5.0$} \\
\hline Cultivation: $31.4 \%$ of DC & \multicolumn{2}{|l|}{$\$ 111.0$} & \multicolumn{2}{|l|}{$\$ 2.7$} \\
\hline Harvest: $60 \%$ of DC & \multicolumn{2}{|l|}{$\$ 55.7$} & \multicolumn{2}{|l|}{$\$ 2.0$} \\
\hline Other: $14 \%$ of DC & \multicolumn{2}{|l|}{$\$ 8.0$} & \multicolumn{2}{|l|}{$\$ 0.2$} \\
\hline Fixed Cap. Invest. (FCI) & \multicolumn{2}{|l|}{$\$ 678.4$} & \multicolumn{2}{|l|}{$\$ 18.6$} \\
\hline Downstream CAPX (M\$) & $\begin{array}{l}\text { Baseline } \\
\text { HTL }\end{array}$ & $\begin{array}{l}\text { Protein } \\
\text { Extraction }\end{array}$ & Fractionation & $\begin{array}{l}\text { First-of-a- } \\
\text { Kind }\end{array}$ \\
\hline HTL - Installed & $\$ 81.4$ & $\$ 63.5$ & $\$ 39.6$ & $\$ 5.0$ \\
\hline CHG & $\$ 80.2$ & $\$ 63.0$ & $\$ 40.3$ & $\$ 6.4$ \\
\hline HT/HC/Aux & $\$ 71.2$ & $\$ 59.0$ & $\$ 44.2$ & $\$ 4.6$ \\
\hline HTL Total Installed & $\$ 232.80$ & $\$ 185.5$ & $\$ 124.1$ & $\$ 16.0$ \\
\hline Protein Extraction & - & $\$ 31.9$ & - & - \\
\hline Fractionation & - & - & $\$ 93.0$ & - \\
\hline Total Installed Cost (TIC) & $\$ 232.8$ & $\$ 217.4$ & $\$ 217.1$ & $\$ 16.0$ \\
\hline Other Direct (14.5\% of TIC) & $\$ 33.8$ & $\$ 31.5$ & $\$ 31.5$ & $\$ 2.3$ \\
\hline Total Direct Costs (TDC) & $\$ 266.6$ & $\$ 248.9$ & $\$ 248.6$ & $\$ 18.3$ \\
\hline Indirect (60\% of TDC) & $\$ 159.9$ & $\$ 149.3$ & $\$ 149.1$ & $\$ 11.0$ \\
\hline Fixed Cap. Invest. (FCI) & $\$ 426.5$ & $\$ 398.2$ & $\$ 397.7$ & $\$ 29.3$ \\
\hline TOTAL SYSTEM FCI & $\$ 1,104.9$ & $\$ 1,076.6$ & $\$ 1,076.0$ & $\$ 47.9$ \\
\hline Land & $\$ 37.8$ & $\$ 37.8$ & $\$ 37.8$ & $\$ 1.1$ \\
\hline Fixed OPX (M\$ / yr) & & & & \\
\hline Labor: Upstream & $\$ 6.8$ & $\$ 6.8$ & $\$ 6.8$ & $\$ 1.2$ \\
\hline Labor: Downstream & $\$ 2.1$ & $\$ 2.1$ & $\$ 2.1$ & $\$ 0.5$ \\
\hline Burdon (90\% of Labor) & $\$ 8.0$ & $\$ 8.0$ & $\$ 8.0$ & $\$ 1.5$ \\
\hline Maintenance: $0.952 \%$ of Upstrm TIC & $\$ 4.4$ & $\$ 4.4$ & $\$ 4.4$ & $\$ 0.1$ \\
\hline Maintenance: $3 \%$ of Dwnstrm TIC & $\$ 7.0$ & $\$ 6.5$ & $\$ 6.5$ & $\$ 0.5$ \\
\hline Insurance + Tax: $0.7 \%$ of System FCI & $\$ 7.7$ & $\$ 7.5$ & $\$ 7.5$ & $\$ 0.2$ \\
\hline Total Fixed OPX / yr & $\$ 36.1$ & $\$ 35.4$ & $\$ 35.4$ & $\$ 4.0$ \\
\hline
\end{tabular}

